\title{
Response of stem cells from different origins to biphasic calcium phosphate bioceramics
}

\author{
Sonja E. Lobo • Robert Glickman • Wagner N. da Silva • \\ Treena L. Arinzeh • Irina Kerkis
}

Received: 23 May 2014 / Accepted: 5 January 2015 / Published online: 13 February 2015

(C) The Author(s) 2015. This article is published with open access at Springerlink.com

\begin{abstract}
Biphasic calcium phosphate (BCP) bioceramics have been successfully applied in a broad variety of presentation forms and with different ratios of hydroxyapatite (HA) and $\beta$-tricalcium phosphate ( $\beta$-TCP). BCPs have been loaded with stem cells from different origins for bone tissue engineering purposes, but evidence of stem cell behavior on different compositions (various HA/ $\beta$-TCP ratios) and physical features of BCPs is limited. We compared the adhesion, proliferation, viability and osteogenic potential of human mesenchymal stem cells (MSCs) on granular BCPs with equal HA/ $\beta$ TCP ratio of diverse particle sizes and on porous blocks which had different chemical compositions. In addition, the osteogenic differentiation of MSCs was compared to adiposederived (ADSC) and dental pulp (DPSC) stem cells, as well as to pre-osteoblasts on a particulate BCP. MSCs growing on granular BCPs demonstrated increased number as compared to MSCs growing on blocks. Cells proliferated to a greater extent on small granular BCPs, while large granular BCPs and blocks promoted cell differentiation. Surprisingly, the expression of genes involved in osteogenesis was upregulated in
\end{abstract}

\footnotetext{
S. E. Lobo $\cdot$ I. Kerkis

Department of Morphology and Genetics, Federal University of São Paulo, São Paulo, Brazil

S. E. Lobo

Department of Biomaterials \& Biomimetics, College of Dentistry,

New York University, New York, NY, USA

R. Glickman

Department of Oral and Maxillofacial Surgery, College of Dentistry,

New York University, New York, NY, USA

e-mail: rsg1@nyu.edu

W. N. da Silva

Department of Orthopaedic Surgery Prof. Matta Machado, Hospital

da Baleia, Belo Horizonte, Minas Gerais, Brazil

e-mail: wagner_nogueira@hotmail.com
}

MSCs on bioceramics in basal medium which indicates that BCPs may have osteoinductive potential. This was confirmed with the upregulation of osteochondrogenic markers, at different time points, when stem cells from various tissues were grown on the BCP. This study demonstrates that BCPs, depending on their physical features and chemical composition, modulate stem cell behavior, and that stem cells from different origins are inherently distinct in their gene expression profile and can be triggered toward osteochondrogenic fate by BCPs.

Keywords Hydroxyapatite $\cdot \beta$-tricalcium phosphate . Mesenchymal stem cells $\cdot$ Adipose-derived stem cells $\cdot$ Dental pulp stem cells
Abbreviations
ADSC Adipose-derived stem cell
ALP Alkaline phosphatase
BCP Biphasic calcium phosphate bioceramics
BSP Bone sialoprotein
$\beta$-TCP Beta tricalcium phosphate

Department of Biomedical Engineering, New Jersey Institute of Technology, Newark, NJ, USA

T. L. Arinzeh

e-mail: arinzeh@njit.edu

I. Kerkis $(\square)$

Department of Genetics, Butantan Institute, Avenida Vital Brasil, 1500, São Paulo, Brazil 05503-900

e-mail: ikerkis@butantan.gov.br

S. E. Lobo $(\square)$

Department of Surgery, School of Veterinary Medicine and Animal Science, University of São Paulo, Avenida Prof. Dr. Orlando

Marques de Paiva, 87, São Paulo, Brazil 05508-270

e-mail: sonja.e.lobo@gmail.com 


$\begin{array}{ll}\text { C } & \text { Control (basal) medium } \\ \text { CI } & \text { Confidence interval } \\ \text { DPSC } & \text { Dental pulp stem cell } \\ \text { HA } & \text { Hydroxyapatite } \\ \text { MSC } & \text { Mesenchymal stem cell } \\ \text { OPN } & \text { Osteopontin } \\ \text { OS } & \text { Osteoinductive medium } \\ \text { TCP } & \text { Tissue culture plate }\end{array}$

\section{Introduction}

Successful reconstruction of critical size bone defects requires bone grafts or graft materials capable of restoring function by promoting new bone ingrowth and adequate biomechanical support. Biphasic calcium phosphate bioceramics (BCP) have been considered optimum bone graft substitutes due to their proven safety, osteoconductivity, bioactivity, biocompatibility, unlimited availability and their potential use as a scaffold for tissue engineering and drug delivery systems (Ohgushi and Caplan 1999; Le Nihouannen et al. 2007; Saldaña et al. 2009; Cheng et al. 2010; Lobo and Livingston Arinzeh 2010; Schumacher et al. 2010; Wang et al. 2010; Yuan et al. 2010). BCP scaffolds, composed of different ratios of hydroxyapatite (HA) and $\beta$-tricalcium phosphate ( $\beta$-TCP), can have a variety of surface topographies, pore sizes and porosities (Arinzeh et al. 2005; Mastrogiacomo et al. 2006; Fellah et al. 2010) and have been widely used in several forms, such as granules or particulates, blocks, cements and custom-made implants. These biomaterials can also be fabricated as composites with natural and polymeric materials, thus fulfilling a broad range of clinical demands that include non-loading and load-bearing sites as well as the reconstruction of major bone defects (Ohgushi and Caplan 1999; Livingston et al. 2003; Marcacci et al. 2007; Matsushima et al. 2009; Saldaña et al. 2009; Schumacher et al. 2010; Teixeira et al. 2010; Weir and Xu 2010; Garrido et al. 2011; Fig. 1).

Biomaterials with different presentation forms have distinct clinical applications. For instance, granules and cements are normally used to fill bone cavities that result from bone cysts and tumors; granules are also used to restore areas where the need for faster bone formation surpasses the requirement for higher stability and mechanical strength. Alternatively, blocks, pre-shaped devices (such as wedges and cages) and custom-made implants (designed specifically for each patient) are usually for sites subjected to high loads and for aesthetic and accurate anatomical reconstruction immediately after the surgical procedure (de Oliveira et al. 2007; Garrido et al. 2011).

The diversity of tissue response and mechanical properties achieved in BCP scaffolds are a consequence of their chemical and physical structures. Some BCPs have been classified as osteoinductive due to their capacity to modify gene expression of human osteogenic and osteosarcoma cells and to heterotopically induce bone formation, in in vivo models, without the addition of bioactive molecules such as BMP (bone morphogenetic protein), mostly in large animal models (Rochet et al. 2003; Yuan et al. 2010; Barradas et al. 2011). Recent studies have shed light on molecular mechanisms that explain this intrinsic osteoinduction property which has been attributed primarily to the chemical composition and physical features, such as surface topography and size and shape of pores of the biomaterial (Ripamonti 1996; LeGeros 2008; Cheng et al. 2010; Yuan et al. 2010; Barradas et al. 2011; Shih et al. 2014; Xia et al. 2014).

Nanostructured BCPs, composed of $65 \% \mathrm{HA} / 35 \%$ B-TCP (Osteosynt ${ }^{\circledR}$; EINCO Biomaterial, Belo Horizonte, Minas Gerais, Brazil), which have interconnecting micro- and macropores (diameters $<10$ and $>100 \mu \mathrm{m}$, respectively) (LeGeros et al. 2003; Lobo and Livingston Arinzeh 2010) and various forms, have been successfully used in orthopaedic and craniofacial applications (de Oliveira et al. 2007; Garrido et al. 2011; Fig. 1). However, their potential to be used as scaffolds in combination with stem cells for tissue engineering has not been investigated. Moreover, previous clinical studies have shown that the reconstruction of segmental bone defects that exceed $3 \mathrm{~cm}$ in length in long bones using these bioceramics may require more than one surgical procedure or a longer period of time to heal (Garrido et al. 2011). Thus, alternative therapeutic strategies are needed to reconstruct these challenging defects. The combination of stem cells with BCPs may be a viable approach.

Conversely, for bone tissue engineering applications, stem cells isolated from different tissues have been associated with a wide variety of biomaterials, including bioceramics, in order to enhance bone tissue formation (Laranjeira et al. 2013; Temple et al. 2014). Mesenchymal stem cells isolated from bone marrow (MSCs), adipose-derived stem cells (ADSC) and dental pulp stem cells (DPSC) are the most commonly studied and characterized adult stem cell types (Shi et al. 2001; Rosenbaum et al. 2008; Huang et al. 2009; Gronthos 2011; Utsunomiya et al. 2011; Kerkis and Caplan 2012; Harasymiak-Krzyzanowska et al. 2013). However, the literature is scarce on data that compares the response of different stem cell types cultured on the same biomaterial.

This study was performed based on the hypotheses that: (1) bioceramics presenting distinct chemical composition and physical features elicit differential stem cell response and may be osteoinductive, and that (2) stem cells isolated from various tissues behave differently when seeded on the same type of scaffold. This investigation aimed at analyzing the potential of bioceramics, which have been successfully applied in orthopaedic and craniofacial surgeries (de Oliveira et al. 2007; Garrido et al. 2011), to function as stem cell carriers and to induce their osteogenic differentiation, as well as to compare the potential of bioceramics that present the same 
Fig. 1 Reconstruction of tibial defects caused by tumors $(\mathbf{a}-\mathbf{c})$ and traumatic defects $(\mathbf{d}-\mathbf{f})$ using granules of $\mathrm{BCP}$ corresponding to 20-40 mesh. Postoperative x-rays of the tibia $(\mathbf{a}, \mathbf{b})$ and clinical aspect of the patient (c).

Preoperative image of the bone defect (d) and its postoperative analysis in the lateral (e) and antero-posterior view (f) (provided by Dr. W.N. da Silva)

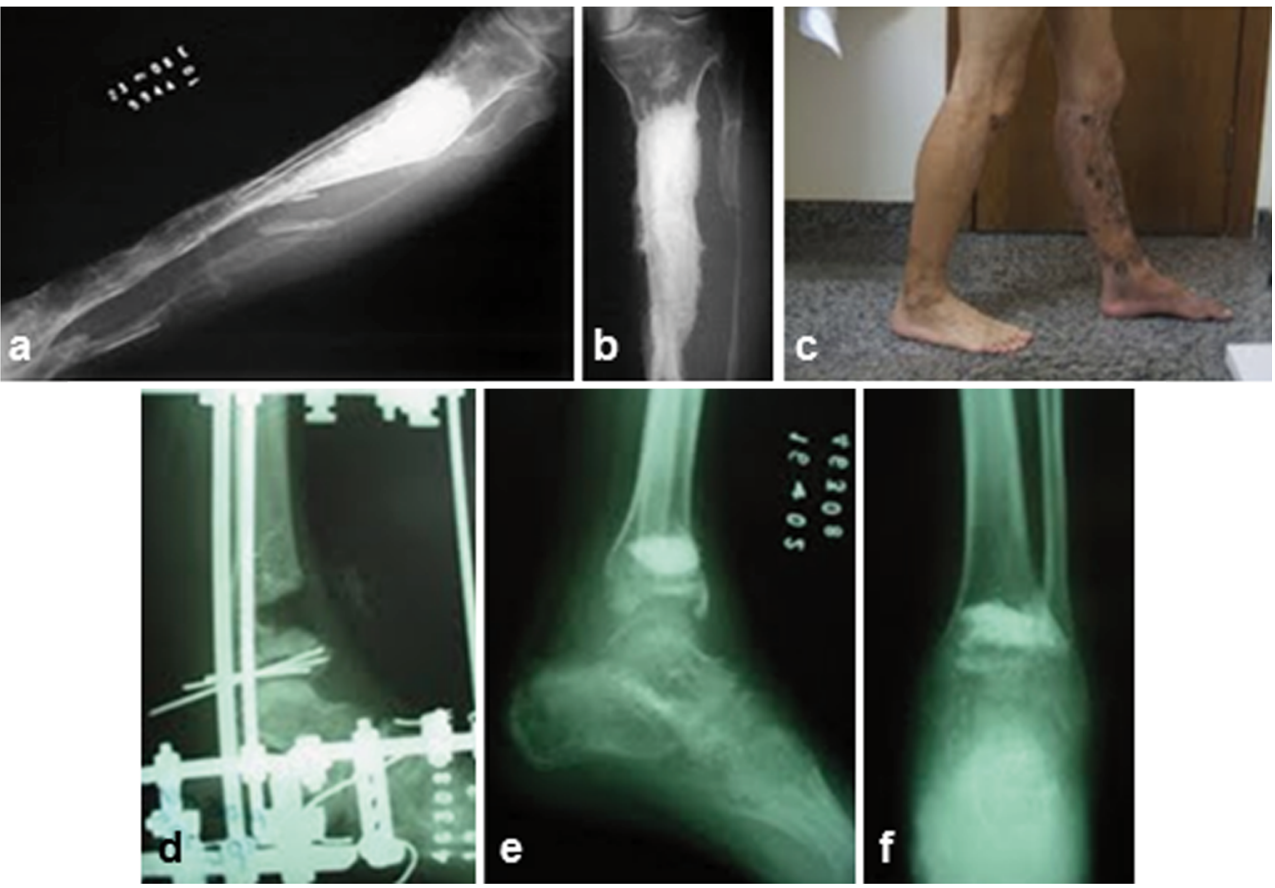

chemical composition and physical structure to trigger osteogenic fate of adult stem cells from different origins. Therefore, the proliferation, viability and osteogenic differentiation of MSCs cultured on six different BCP scaffolds, divided into two groups, granules (G20-40, G40-60 and G60-80) and porous blocks (BCP1, BCP2 and $\mathrm{BCP} 3)$, were evaluated. The granules had the same HA/TCP ratio but varied in physical structure, i.e., granule size. The blocks differed in composition. Cell proliferation and viability were measured using two different assays, DNA content and metabolic activity, over time. The osteogenic differentiation was evaluated by gene expression and alkaline phosphatase activity over time. Moreover, the determination of osteogenic cell fate of MSC, ADSC and DPSC on a granular form of BCP (G20-40) was compared to pre-osteoblasts. Cell adhesion was analyzed using scanning electron microscopy and the expression of genes responsible for the determination of stem cell fate was investigated using RT-PCR.

\section{Materials and methods}

Materials

Nanostructured micro- and macroporous biphasic calcium phosphate (BCP)-based bioceramics were provided by EINCO Biomaterial in the form of granules and blocks. The granules had different particle sizes and were irregular in shape but had the same chemical composition: 65/35 (wt $\%$ / wt $\%$ ) HA/ß-TCP. They were named: G20-40 (corresponding to granules of 20-40 mesh, with largest diameter of up to
$1.5 \mathrm{~mm}$ ); G40-60 (granules of 40-60 mesh, where the largest diameter corresponded to $1 \mathrm{~mm}$ ); and G60-80 (corresponding to particles of 60-80 mesh, which had an average of $0.7 \mathrm{~mm}$ at the largest diameter). The blocks, $5 \mathrm{~mm}$ in diameter and $2 \mathrm{~mm}$ in thickness, had different chemical compositions: BCP1 was composed of $65 / 35 \% \mathrm{HA} / \mathrm{B}-\mathrm{TCP}$, i.e., the same composition of the granules, BCP2 was a composite of HA and poly(methyl 2-methylpropenoate), and BCP3 was composed of $10 \% / 90 \% \mathrm{HA} / \beta$-TCP ratio (Table 1 ). The chemical composition was verified by XRD (data not shown). The surface topographies were assessed qualitatively by scanning electron

Table 1 Chemical composition, physical forms and porosity of the six different BCP scaffolds

\begin{tabular}{|c|c|c|c|c|c|}
\hline \multirow[t]{2}{*}{ Samples } & & \multirow{2}{*}{$\begin{array}{l}\text { Chemical } \\
\text { composition } \\
\text { (HA/ } \beta \text {-TCP ratio) }\end{array}$} & \multirow{2}{*}{$\begin{array}{l}\text { Physical } \\
\text { form }\end{array}$} & \multicolumn{2}{|c|}{ Porosity } \\
\hline & & & & Micro & Macro \\
\hline \multirow[t]{6}{*}{ Bioceramics } & G20-40 & $65 \% / 35 \%$ & Granules & $* * *$ & $* * *$ \\
\hline & G40-60 & $65 \% / 35 \%$ & Granules & $* * *$ & $* *$ \\
\hline & G60-80 & $65 \% / 35 \%$ & Granules & $* * *$ & $*$ \\
\hline & $\mathrm{BCP} 1$ & $65 \% / 35 \%$ & Blocks & $* * *$ & $* *$ \\
\hline & $\mathrm{BCP} 2$ & $100 \% \mathrm{HA} /$ polymer & Blocks & $* * *$ & $* * *$ \\
\hline & BCP3 & $10 \% / 90 \%$ & Blocks & $* * *$ & $* *$ \\
\hline
\end{tabular}

The BCPs were granules (G20-40, G40-60 and G60-80) and blocks (BCP1, BCP2 and BCP3). Granules had the same microporosity $(<10 \mu \mathrm{m})$ but different particle sizes and macroporosity $(>100 \mu \mathrm{m})$ (observed by SEM). The granules and BCP1 had the same chemical composition but different physical features. Blocks had different compositions and surface topographies. For porosity, a semi-quantitative grading system varying from 3 to 1 asterisks was used for high to low porosity, respectively 
microscopy (SEM) viewing of the scaffolds' surface. For the comparative analysis of osteogenic differentiation of stem cells from distinct origins, the granules G20-40 were used.

\section{Cell culture}

Human mesenchymal stem cells (MSCs) were isolated from whole bone marrow from male donors, 18-30 years old (Lonza, USA), as previously reported (Briggs et al. 2009), and cultured in control media composed of Dulbecco's Modified Eagle's Medium low glucose (Gibco; Invitrogen, Carlsbad, CA, USA), supplemented with $10 \%$ fetal bovine serum (HyClone; Thermo Fisher Scientific, USA) and 100 units/ml antibiotic-antimycotic (Invitrogen). Adipose-derived stem cells (ADSC; Poietics Human Adipose-Derived Stem Cells) were purchased from Lonza (Walkersville, MD, USA) and grown in ADSC Growth Medium (Bulletkit; Lonza). Dental pulp stem cells (DPSC) were isolated from third molars extracted at the Department of Oral Surgery at New York University College of Dentistry (reviewed and approved by the Committee of Ethics), as previously reported (Kerkis et al. 2006). Briefly, after extraction, teeth were cleaned with povidine, and odontosection was performed at the cemento-enamel level using a low rotation saw under profusion irrigation with saline solution. After exposure of the pulp chamber, pulp tissue was removed from the crown and roots, under sterile conditions, and placed in Petri dishes with DMEM/F12 media (Gibco; Invitrogen) supplemented with $15 \%$ FBS (HyClone ${ }^{\circledR}$; Thermo Fisher Scientific), 100 units/ml of penicillin/streptomycin (SigmaAldrich, St. Louis, MO, USA), 2 mM L-glutamine (Gibco; Invitrogen) and $2 \mathrm{mM}$ non-essential amino acids (Gibco, Invitrogen). The pulp was incubated at $37{ }^{\circ} \mathrm{C}, 5 \% \mathrm{CO}_{2}$, for separation of stem cells from the extracellular matrix through explant. Cells have been characterized elsewhere with regard to their multipotency and cell membrane markers and shown to be stem cells. Human pre-osteoblasts (MG-63; Lonza) were cultured in Alpha-MEM (Minimum Essential Medium Alpha; Gibco, Invitrogen), supplemented with 10 \% FBS (HyClone; Thermo Fisher Scientific) and 100 units/ml of penicillin/ streptomycin (Sigma-Aldrich).

Cells were expanded in control medium (basal medium) until passage 3 and seeded onto the BCP scaffolds at $3 \times 10^{4}$ cells $/ \mathrm{cm}^{2}$ in polypropylene plates. Cells on scaffolds were grown in control and osteogenic media (OS), comprised of control media supplemented with $100 \mathrm{nM}$ of dexamethasone, $0.05 \mathrm{mM}$ of ascorbic acid and $10 \mathrm{mM}$ of $\beta$-glycerophosphate. As control groups, cells were seeded directly on tissue culture polystyrene plates (TCP) and cultured in both control (C) and osteoinductive medium (OS), without scaffolds. In order to avoid eventual influences on cell growth, viability, adhesion and/or differentiation provided by the growth media, the osteogenic media was used in the respective groups from the time of cell seeding (i.e., control media was not initially applied and later changed to OS media). Media was changed every 2-3 days and the cells were kept in a $5 \% \mathrm{CO}_{2}$ incubator at $37{ }^{\circ} \mathrm{C}$.

\section{Scanning electron microscopy}

The physical features (presence of pores and surface topographies) of the BCPs as well as stem cells and pre-osteoblast morphologies and adhesion to the scaffolds were observed using SEM (Hitachi S-3500 N LV-SEM, Singapore). The constructs (stem cells on scaffolds) were washed twice with PBS and fixed with Karnovsky solution (Karnovsky Fixative, Electron Microscopy Sciences, Hatfield, PA, USA). The samples were then subjected to serial dehydration with $10,30,50$, $70,80,90$, and $100 \%$ ethanol, dried overnight with $1,1,2-$ triclorofluorethane and gold-coated. Bioceramics without stem cells were directly coated with gold. Two samples of each scaffold were analyzed and the constructs were evaluated after $4 \mathrm{~h}$, and 1, 7 and 14 days of culture.

\section{Cell proliferation}

Cell number was quantified using Quanti-iT PicoGreen dsDNA Assay Kit (Molecular Probes, Invitrogen, USA). Briefly, the cells were lysed using $0.1 \%$ Triton X-100 for $30 \mathrm{~min}$ and incubated at room temperature for $5 \mathrm{~min}$ with the fluorochrome PicoGreen, which stains the nucleic acid by selective binding to the double-stranded DNA. The plates were read on the spectrophotometer FLX800 microplate reader using KC Junior software at wavelength of $480 \mathrm{~nm}$ and emission corresponding to $520 \mathrm{~nm}$. Fours samples per group per time point were studied; the assay was repeated twice and the analysis was performed at days 4, 7, 11 and 14 .

\section{Cell viability}

The cell viability was quantified using the XTT assay (XTT Cell Viability Assay Kit; Biotium, Hayward, CA, USA), which measures the activity of the mitochondrial enzymes, according to the manufacturer's protocol. The cell viability was determined using a standard curve correlating absorbance values to standards of known cell numbers. The absorbance was measured with a spectrophotometer at wavelength of $450 \mathrm{~nm}$. Four samples per group per time point were studied and the assays were repeated twice. Samples were analyzed at 4,11 and 14 days of culture.

\section{qRT-PCR}

The total RNA was isolated using Qiagen RNAeasy Kit (Qiagen, CA, USA) and the DNA was excluded using RNase Free DNase Set. Quantitative reverse transcriptasepolymerase chain reaction (qRT-PCR) was performed using 
One Step QuantiTect SYBR Green RT-PCR Kit (Qiagen), according to the manufacturer's instructions. Specific oligonucleotide primers for bone sialoprotein (integrin-binding sialoprotein, IBSP; QT00093709); osteopontin (secreted phosphoprotein 1, SPP; QT01008798); RUNX2 (runt-related transcription factor 2; QT00020517); SOX9 (SRY [sex determining region Y]-box 9; QT00001498); PPAR $\gamma$ (peroxisome proliferator-activated receptor; QT00029841); SOX2 (SRY-box 2; QT00237601) were analyzed and their relative gene expression was normalized to the relative expression of the housekeeping gene RPLP0 (ribosomal protein P0; QT01839887) or GAPDH (glyceraldehyde-3-phosphate dehydrogenase; QT01192646). Samples were analyzed at days $1,3,7$ and/or 14, assayed in triplicate for each time point, and repeated twice. The reverse transcription was performed for $30 \mathrm{~min}$ at $50{ }^{\circ} \mathrm{C}$, the PCR activation for $15 \mathrm{~min}$ at $95^{\circ} \mathrm{C}$, and the amplification reactions were carried out through 40 cycles ( $15 \mathrm{~s}$ denaturation at $94^{\circ} \mathrm{C}, 30 \mathrm{~s}$ of annealing at $55^{\circ} \mathrm{C}$ and $30 \mathrm{~s}$ of extension at $72{ }^{\circ} \mathrm{C}$ ) using the MX4000 detection system (Stratagene, USA).

\section{Alkaline phosphatase activity}

The alkaline phosphatase activity was measured using the $\mathrm{p}$ Nitrophenyl phosphate assay (Sigma-Aldrich, USA) according to the manufacturer's protocol. The absorbance was measured at $405 \mathrm{~nm}$ using a spectrophotometer (Molecular
Devices, USA). Four samples per group per time point were studied and the assay was repeated twice. Alkaline phosphatase activity was normalized to cell number, i.e., data from the proliferation analysis (Quanti-iT PicoGreen dsDNA Assay). The analyses were performed at days 7,11 and 14 .

\section{Statistical analysis}

Statistical analysis was performed using Bonferroni multiplesignificance test where comparisons for each one and between the variables (time points, cell culture media, with and without biomaterials and differences among biomaterials) were performed $(p<0.05)$.

\section{Results}

All scaffolds had nanostructured surfaces with similar micropores $(<10 \mu \mathrm{m})$ as observed by SEM. The macropores $(>100 \mu \mathrm{m})$ as well as the surface topographies appeared to vary among the six scaffolds. Macropores were observed in all the scaffolds but to a lesser extent in the G60-80 group. Among the blocks, the group BCP2 had the most irregular surface and appeared to have more macropores (Figs. 2 and 3). Cells were observed to adhere to the surface of all the scaffolds and to penetrate their porous
Fig. 2 SEM images of the granules with different particle sizes (20-40 mesh, 40-60 mesh, and 60-80 mesh). The shape and size of the granules (a, a', a"), the size and presence of macropores (b, b', b") and the micropores (c, c', c") can be observed. Bars (a, a', a") $1 \mathrm{~mm},(\mathbf{b}, \mathbf{b}, \mathbf{b} ")$ $100 \mu \mathrm{m},(\mathbf{c}, \mathbf{c}, \mathbf{c} ") 10 \mu \mathrm{m}$

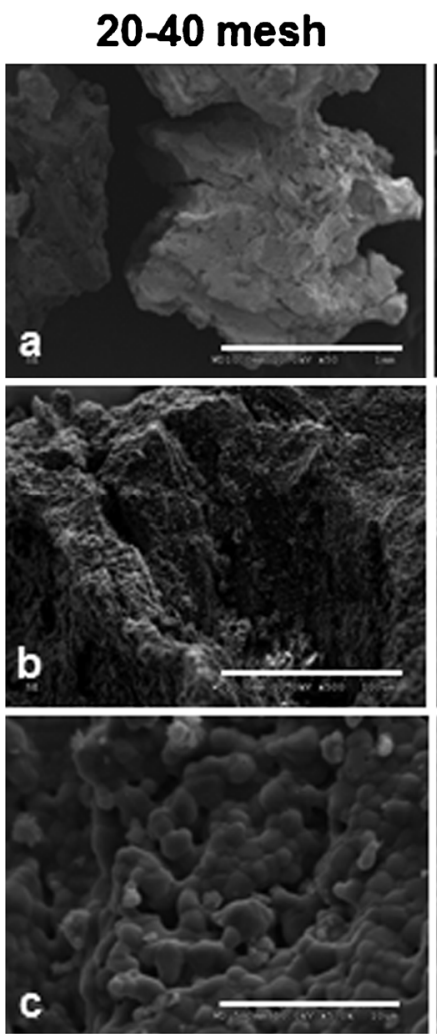

40-60 mesh
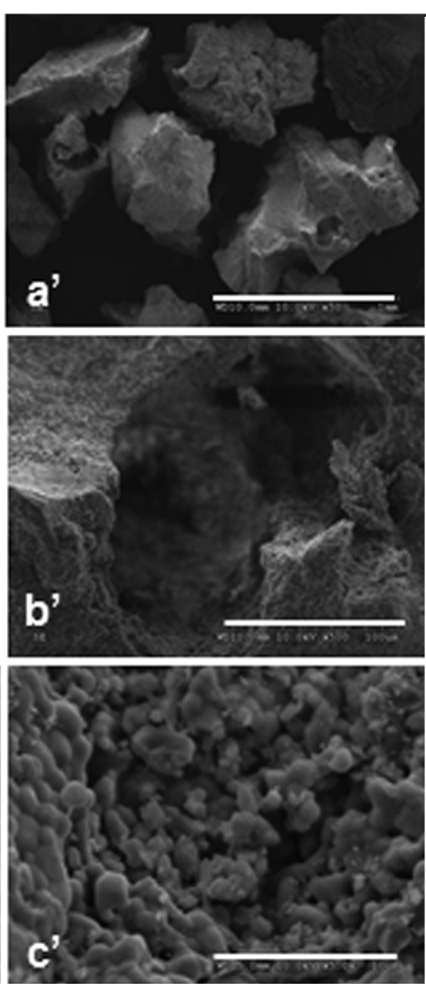

60-80 mesh
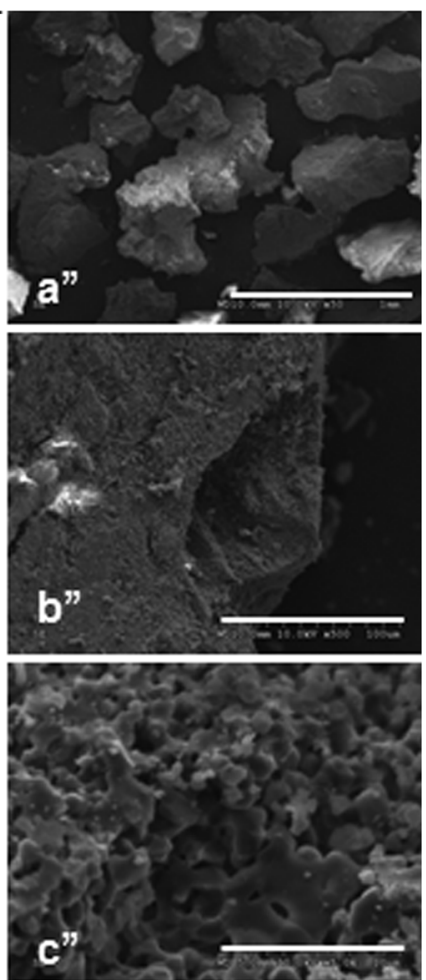
Fig. 3 SEM images of the blocks (BCP1, BCP2 and BCP3) showing distinct surface topographies (a, a', a"). Variation in the size and amount of macropores $(\mathbf{b}, \mathbf{b}$ ', $\mathbf{b}$ ") were seen whereas the presence of micropores $\left(\mathbf{c}, \mathbf{c},, \mathbf{c}^{\prime \prime}\right)$ were observed in all of the scaffolds. $\operatorname{Bars}(\mathbf{a}, \mathbf{a}, \mathbf{a}$ ") $1 \mathrm{~mm},(\mathbf{b}, \mathbf{b}, \mathbf{b} ")$ $100 \mu \mathrm{m},(\mathbf{c}, \mathbf{c}, \mathbf{c} ") 10 \mu \mathrm{m}$
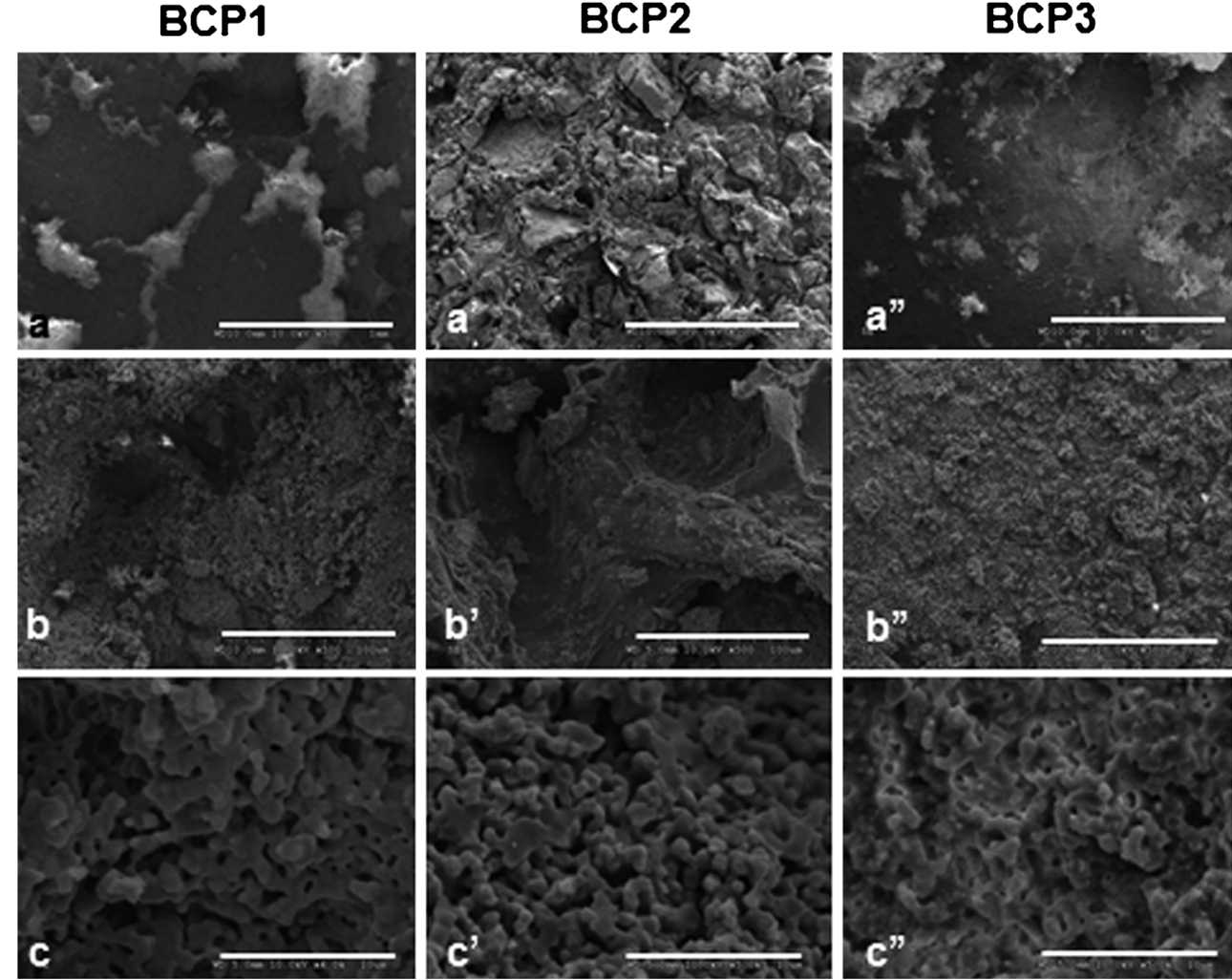

Fig. 4 Morphological aspects of stem cells and pre-osteoblasts on tissue culture plate (a, a', a", a"') and on bioceramics G20-40 (b, b', b", b"' and c, c', c", c"'), in control media, at day 7 . Under light microscopy, pre-osteoblasts (MG-63) had round-shaped morphology compared to stem cells (a, a', a", a"'). When seeded on the bioceramics, eventual distinct morphological features of the cells are not distinguishable $(\mathbf{b}, \mathbf{b}, \mathbf{b}$ ", b"', c, c', c', c'"'). MSC mesenchymal stem cells, $A D S C$ adipose-derived stem cells, DPSC dental pulp stem cells. Scale bars (SEM) $50 \mu \mathrm{m}$

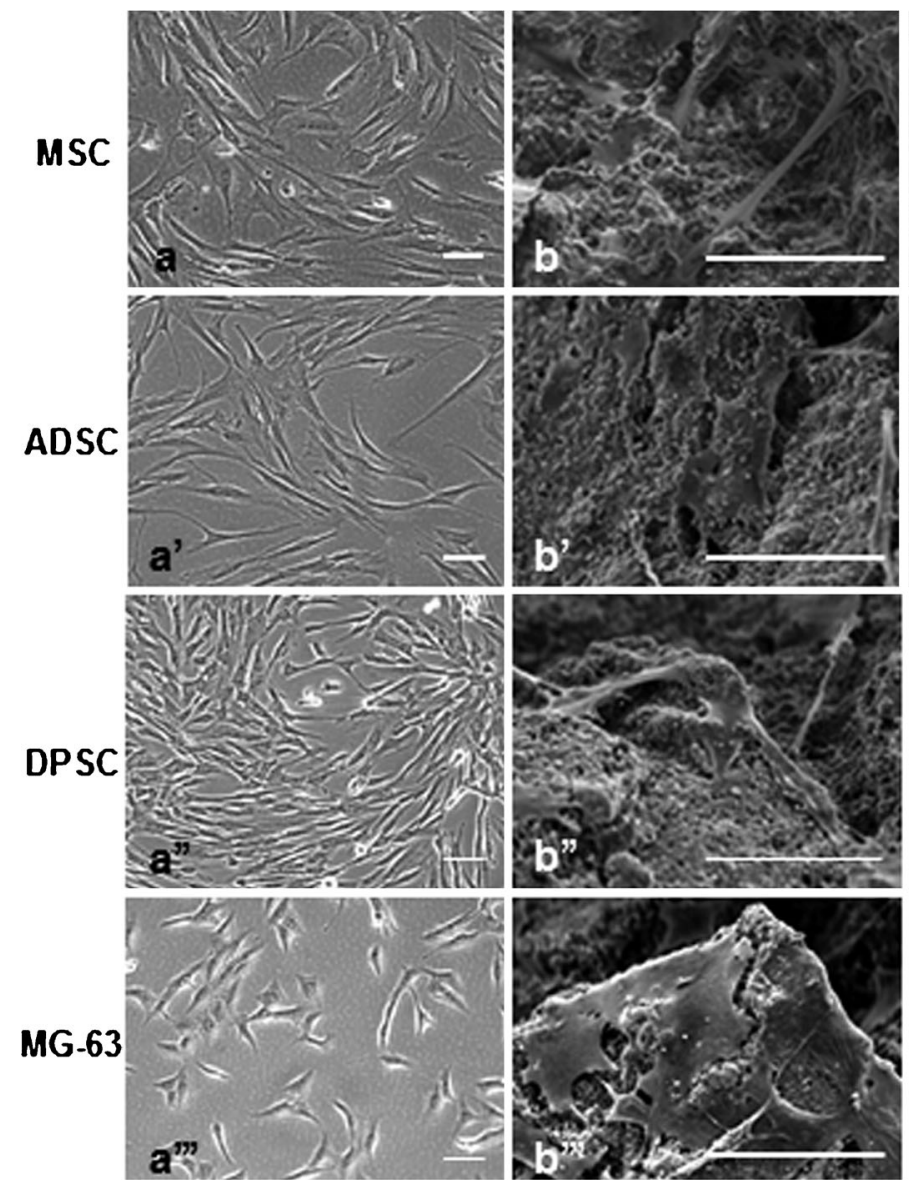

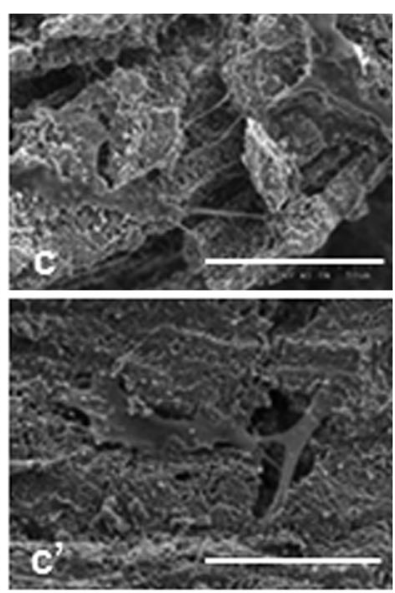
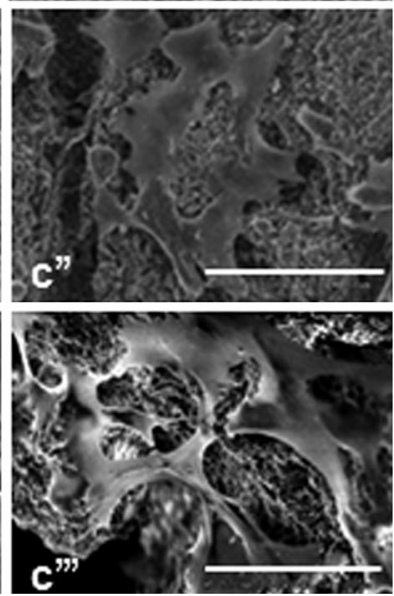
structure. Stem cells from various tissues and pre-osteoblasts had slightly different morphologies when cultured directly on polystyrene plates (Fig. 4). Dental pulp stem cells were found to extend multiple filopodia-like protrusions within hours after seeding which allowed them to adhere to the surfaces of the bioceramics (Fig. 5). Thereafter, cells spread on the surface and inside the pores of the BCP scaffolds (Fig. 4).

Cell number was higher on granules as compared to blocks (Fig. 6). Almost all groups showed the highest cell number at day 11 of culture. The cells cultured directly on polystyrene
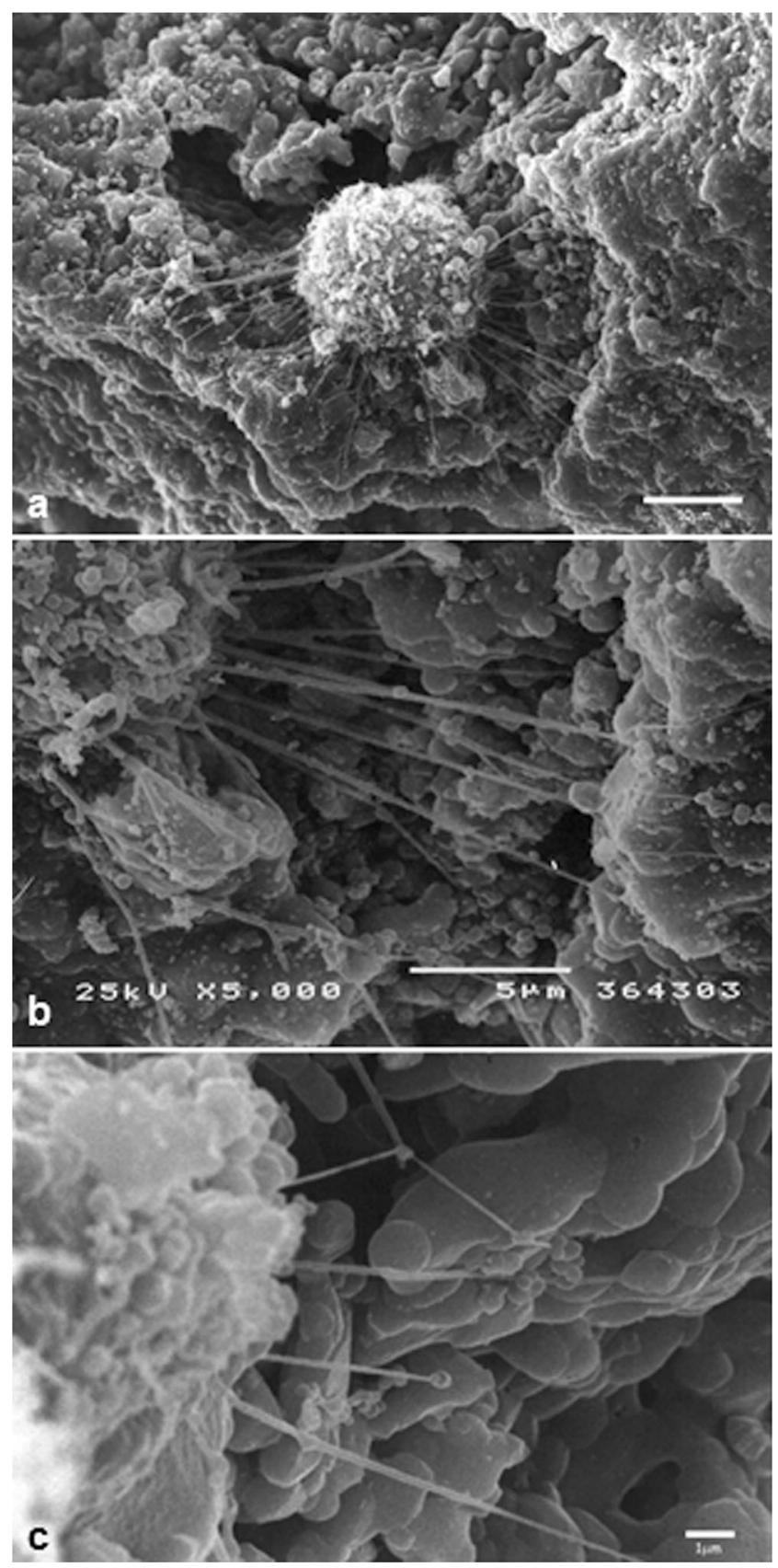

Fig. 5 Initial adhesion of a dental pulp stem cell, $4 \mathrm{~h}$ after seeding on granules G20-40, mediated by the emission of filopodia-like structures. Scale bars (a) $10 \mu \mathrm{m}$, (b-) $5 \mu \mathrm{m}$, (c) $1 \mu \mathrm{m}$ plates showed higher number in osteogenic media as compared to the control media $(p<0.05)$. However, cells cultured on the BCPs did not show statistically significant differences between both media (control and osteogenic). The group G6080 (granules with the smallest particle size, therefore presenting higher surface area for cell adhesion) in control media showed the highest cell number at day $11(p<0.05)$ (Fig. 6a). Among the blocks, cell number increased in the group BCP2, although it was not statistically significant and was lower than the control group in osteogenic media (MSC OS) (Fig. 6b). Due to the fact that no significant differences in cell proliferation were observed between days 7 and 11 and that the latest (day 11) presented the highest cell number in some experimental groups, day 7 was not included in further assays. The groups G40-60 and BCP2 had the highest number of viable cells amongst all bioceramic groups and G40-60 was equivalent to the control group (Fig. 7).

The expression of bone sialoprotein (BSP) for cells grown on TCP (tissue culture plate) and on granules in OS medium increased over time (Fig. 8a). Interestingly, cells cultured on BCP1 and BCP2 in control medium had an upregulation of BSP as compared to OS medium at day 7. This increased expression was also observed for granules 20-40 mesh (G20-40) and 40-60 mesh (G40-60) at day 7 in control medium as compared to OS medium $(p<0.05)$. BSP expression decreased on BCP3 group in both media over time (Fig. 8b). High level of BSP was detected for the granules of 20 40 mesh in control media at day 7 (Fig. 8).

The expression of osteopontin (OPN) was higher for cells cultured on the bioceramics (granules and blocks) in both media than on TCP (control groups, i.e., MSC C and MSC OS) (Fig. 9). Exception was observed for cells on blocks BCP3 OS at days 7 and 14 and BCP2 OS at day 14, which had equivalent OPN gene expression compared to the group MSC OS. Cells on granules G20-40 in control medium presented the highest OPN expression at day 7 amongst all groups (Fig. 9a). Within the blocks, upregulation of OPN was observed for cells grown on BCP1 (days 1, 7 and 14) and $\mathrm{BCP} 2$ (day 7) in control medium as compared to OS medium (Fig. 9b).

Due to the fact that the G20-40 group showed high BSP and OPN gene expression in control medium, it was used for the comparison of genes expressed at early stages of differentiation by stem cells from different origins as well as pre-osteoblasts. MSC, ADSC and DPSC had distinct profiles of mRNA expression for RUNX2, SOX9 and PPAR $\gamma$ when cultured on TCP and in control (C) media (Figs. 10a, 11a and 12a).

MSC C (control media) on TCP had predominant coexpression of RUNX2 and SOX9 and very low levels of PPAR $\gamma$, at all time points (Fig. 10a). MSC OS (osteogenic media) on TCP had increased expression of PPAR $\gamma$ over time, with a peak on day 14. Furthermore, levels of RUNX-2 also 
Fig. 6 Mesenchymal stem cell proliferation, evaluated by PicoGreen assay, on granules (a) and blocks (b). Higher cell number was determined on granules as compared to all the blocks. Among the granules, the highest cell number among all groups was for the smallest particles (60-80 mesh) in control media $\left({ }^{*} p<0.05\right)$. Among the blocks, higher cell number was determined for $\mathrm{BCP} 2$ but was not statistically significant. $C$ control media; $O S$ osteogenic media $\left({ }^{*} p<0.05\right)$. Values are mean $\pm \mathrm{SE}$
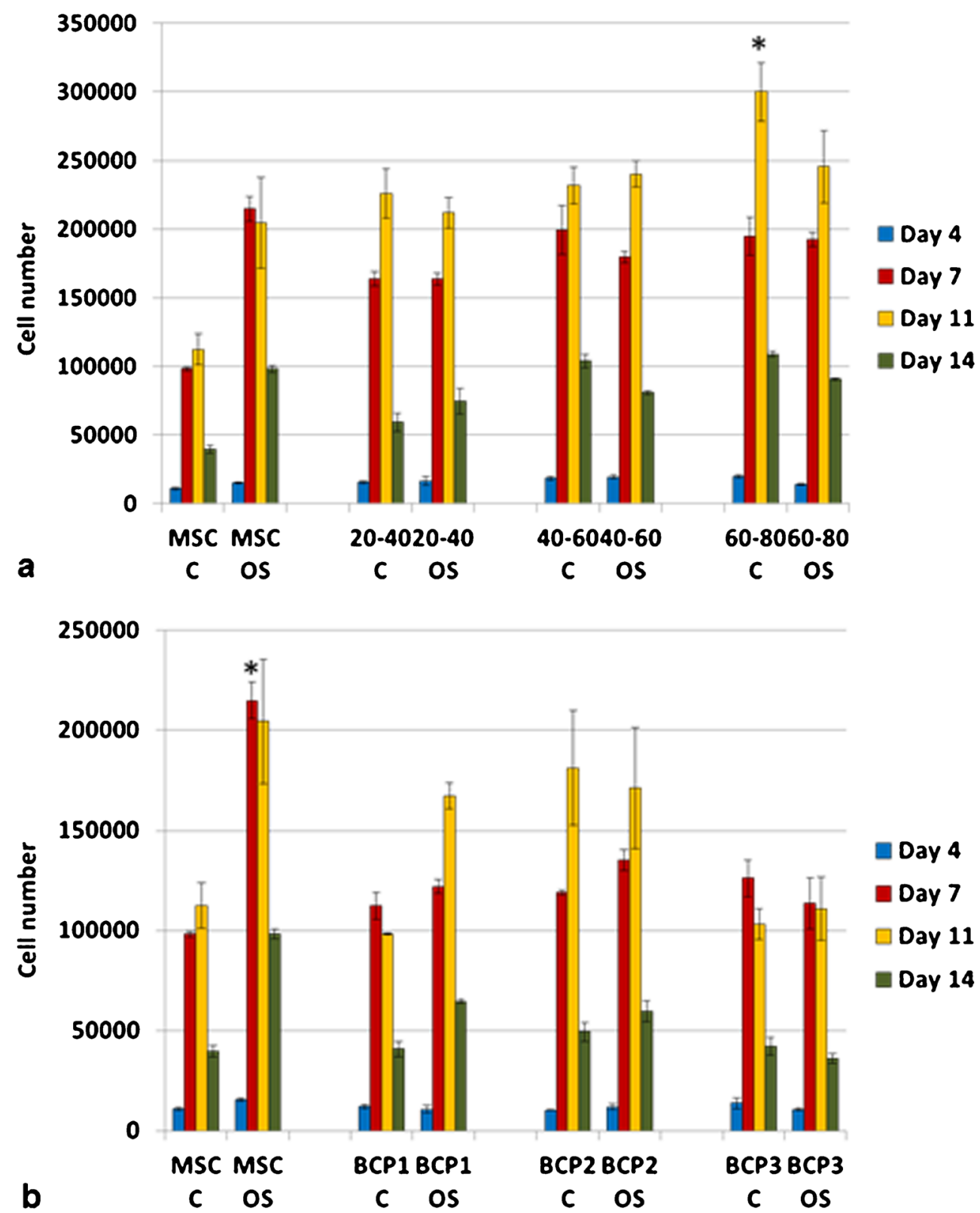

increased from days 1 to 14 , whereas SOX9 was concurrently downregulated. SOX9 had the highest expression for MSC C on TCP on day 14 (Fig. 10a). MSC C on BCP (G20-40) significantly co-expressed RUNX2 and SOX9 throughout the study, and very low levels of PPAR $\gamma$ were detected (Fig. 10b). On day 7, SOX9 expression for MSC C on BCP was higher than those for MSC C on TCP $(p<0.05)$. The levels of RUNX2 and SOX9 for MSC C on BCP on day 3 and of SOX9 on day 7, in the same conditions, were higher than those for MSC OS on BCP (Fig. 10b). MSC OS on BCP showed marked co-expression of RUNX2 and SOX9 on day 1 , which was higher than that for all other groups at the same time point. Conversely, levels of PPAR $\gamma$ were higher on MSC $\mathrm{OS}$ on $\mathrm{BCP}$ in comparison to MSC C on BCP (Fig. 10b).
ADSC C on TCP expressed RUNX2 and SOX9 on days 1 and 3 when PPAR $\gamma$ was not detected. However, on days 7 and 14 , the expression of PPAR $\gamma$ was significantly increased for ADSC C (Fig. 11a). ADSC OS on TCP expressed PPAR $\gamma$ at all time points, differently from ADSC C on TCP (Fig. 11). These cells showed simultaneous upregulation of RUNX2 and SOX9 on day 1 in OS media but, at the later time points, SOX9 was downregulated whereas the expressions of RUNX2 and PPAR $\gamma$ remained high (Fig. 11b). ADSC C on BCP showed simultaneous expression of RUNX2, SOX9, and PPAR $\gamma$ at all time points, although on day 1, RUNX2 was significantly upregulated (Fig. 11b). The levels of PPAR $\gamma$ were lower for ADSC C on BCP compared to those of all other groups; an exception was observed on day 1 for 
Fig. 7 Mesenchymal stem cell viability analyzed by XTT assay showed that the granules (a), had higher viable cells as compared to the blocks (b) $(p<0.05)$. The BCP2 had the highest number of viable cells among the blocks $\left({ }^{*} p<0.05 ; * * p<0.01\right)$. Values are mean $\pm \mathrm{SE}$

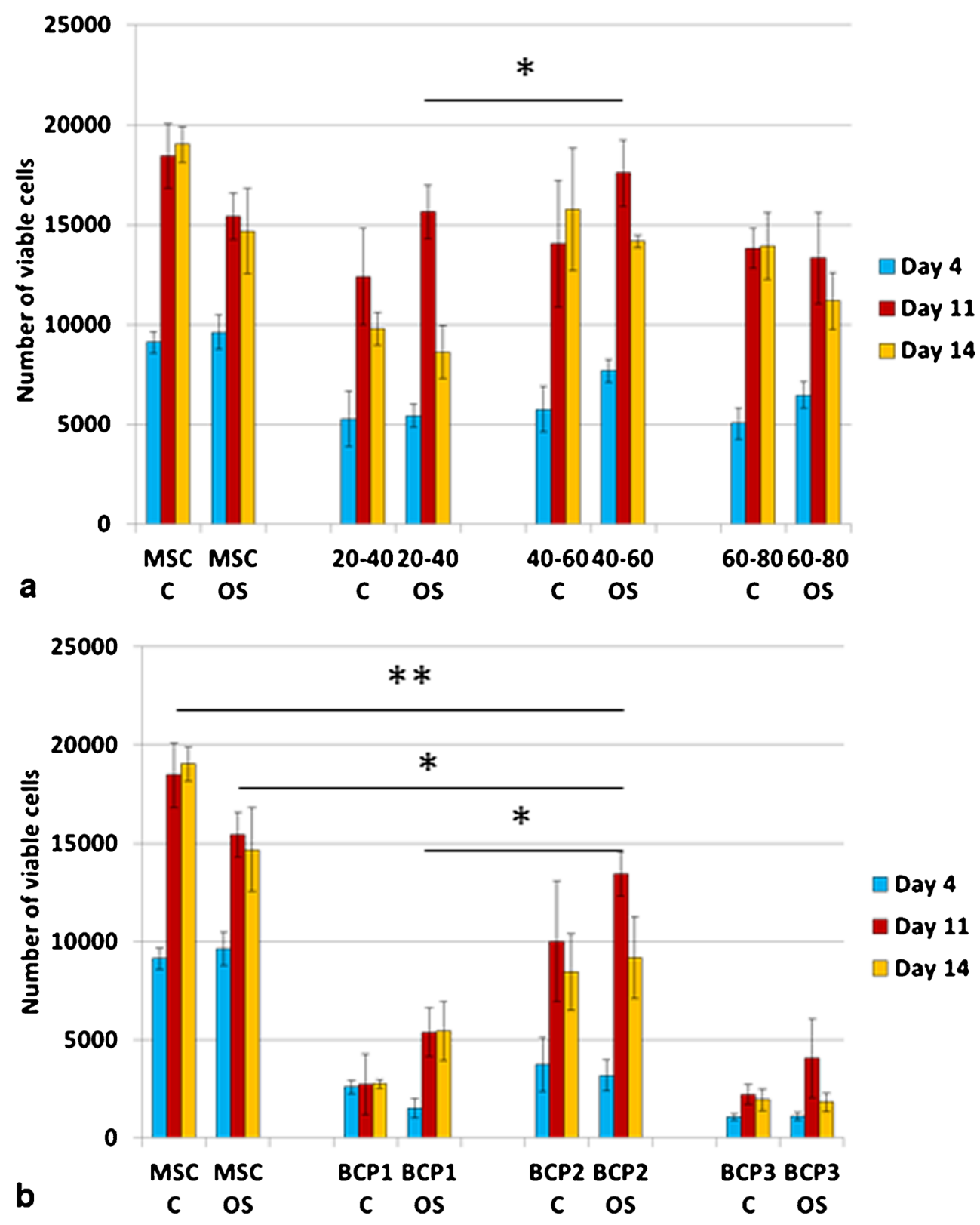

ADSC C on BCP, which expressed more PPAR $\gamma$ compared to ADSC C on TCP. PPAR $\gamma$ was significantly downregulated for ADSC $\mathrm{C}$ on $\mathrm{BCP}$ in comparison to ADSC $\mathrm{C}$ on TCP, on days 3, 7, and 14. On the other hand, ADSC OS on BCP showed increased expression of PPAR $\gamma$ compared to ADSC $\mathrm{C}$ on BCP for all time points (Fig. 11b). These values were, however, lower than those for ADSC OS on TCP. The expression of RUNX2 and SOX9 were similar for ADSC $\mathrm{C}$ on BCP and for ADSC OS on BCP. On day 1, RUNX2 for ADSC C on BCP was higher than that for ADSC $\mathrm{OS}$ on $\mathrm{BCP}$, although this difference was not statistically significant (Fig. 11).

On TCP, DPSC did not express PPAR $\gamma$ in $\mathrm{C}$ media, at any time point but co-expressed RUNX2 and SOX9 (Fig. 12a).
Both DPSC C on TCP and DPSC OS on TCP expressed mostly RUNX2 and SOX9 (Fig. 12a), except for DPSC OS on TCP, in which case low levels of PPAR $\gamma$ were detected on day 7 (Fig. 12a). The absence and very low levels of PPAR $\gamma$ observed with DPSC is in contrast with the relatively very high levels detected for ADSC. The highest gene expression shown by DPSC was for RUNX2, at day 7, in OS media, on TCP. DPSC C and DPSC OS, both on BCP, expressed RUNX2 and SOX9 only (Fig. 12b). In addition, for DPSC on BCP, in both $\mathrm{C}$ and OS media, the SOX9 expression was higher than RUNX2 at all time points except on day 14, when DPSC OS on BCP had equivalent values of RUNX2 and SOX9 (Fig. 12b). DPSC C on BCP elicited higher SOX9 expression than DPSC OS on BCP on days 3, 7, and 14. On 
Fig. 8 Relative expression of bone sialoprotein (BSP) for mesenchymal stem cells on the granules (a) and blocks (b), where the values were normalized to the housekeeping gene (RPLP0). Cells cultured in OS media either on tissue culture polystyrene or on granules had increased BSP expression from day 1 to day 14 $(p<0.05)$. Cells grown on granules of $20-40$ mesh in control media, at day 7 , showed the highest level of mRNA for BSP amongst all groups, including other granules and all blocks $\left({ }^{*} p<0.05\right)$. Cells grown on granules (20-40 mesh) and blocks (BCP1 and BCP2) had higher levels of mRNA for BSP in control media in comparison to OS media at day $7\left({ }^{*} p<0.05\right)$. At day 14 , statistical differences were detected between BCP2 OS and MSC OS $(* * p<0.05)$. Among blocks, BCP2 at day 7 in control media had the highest expression of BSP $(* p<0.05)$. OS osteogenic media. Values are mean $\pm \mathrm{SE}$
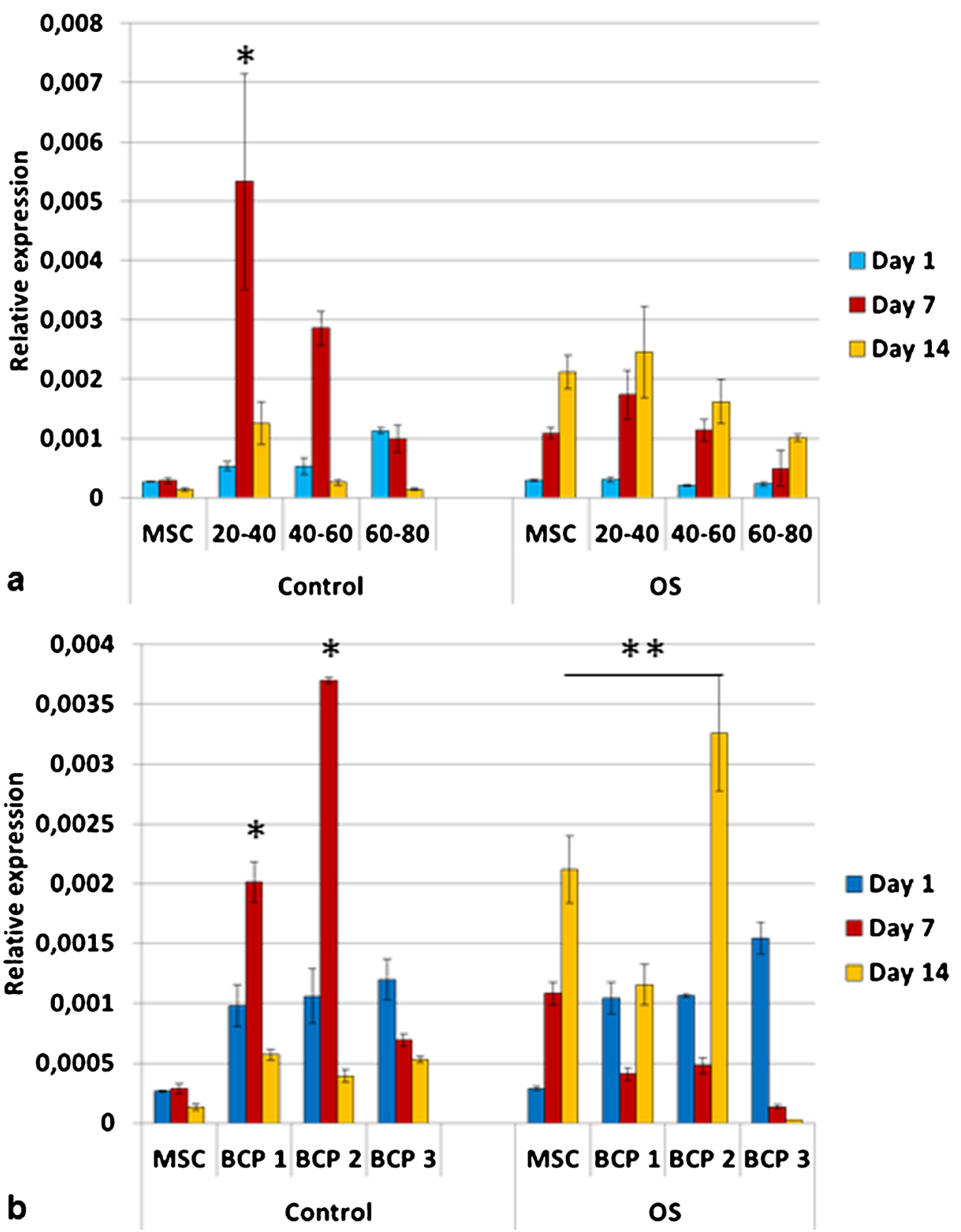

days 3 and 7, SOX9 was higher for DPSC C on BCP than for DPSC OS on BCP (Fig. 12b).

Pre-osteoblasts (MG-63) in C and OS media, on TCP, remarkably expressed SOX9 at all time points (Fig. 13a). On day 1, the levels of RUNX2 and SOX9 for MG-63 OS on TCP were equivalent but, at later time points, SOX9 was upregulated, being significantly higher than RUNX2. No expression of bone sialoprotein (BSP), a later osteogenic maker, was detected for MG-63 on TCP, in both $\mathrm{C}$ and OS media (Fig 13a). MG-63 C on BCP had increased expression of RUNX2 on days 7 and 14 (Fig. 13b). On day 7, the expression of SOX9 was higher for MG-63 C on BCP than for MG-63 OS on BCP (Fig. 13b). In OS media, MG-63 on BCP showed increased co-expression of RUNX2 and SOX9 on day 14. Pre-osteoblasts remarked expressed BSP (bone sialoprotein) only when cultured on BCP, in both media, on day 14 . Here, BSP expression tended to be higher in $\mathrm{C}$ media compared to that in OS media (Fig. 13b).

The alkaline phosphatase (ALP) activity of MSCs on polystyrene plate and on the six BCPs in OS media increased over time and reached the highest values at day 14 (Fig. 14). MSC seeded on bioceramics, granules and blocks, and on tissue culture polystyrene and grown in control media did not show ALP activity (data not shown). Cells on BCP3 in OS medium had the lowest ALP activity and cells on BCP2 in OS medium presented the highest activity amongst all the groups at day 14 (Fig. 14b). 
Fig. 9 Relative expression of osteopontin (OPN) for mesenchymal stem cells on granules (a) and blocks (b) (values were normalized to the housekeeping gene RPLP0). The mRNA levels were higher for cells cultured on the granules for all groups and time points compared to the blocks $\left({ }^{*} p<0.05\right)$. Cells cultured on both G20-40 and G40-60 granules in control medium had higher levels of osteopontin expression as compared to cells cultured on the same biomaterials but in OS medium at day $7(* p<0.05)$. Cells on G20-40 had higher expression of osteopontin than all groups $\left({ }^{*} p<0.05\right)$. Cells on BCP1 in control medium at day 1 and $\mathrm{BCP} 2$ in control medium at day 7 had the highest osteopontin expression among blocks $(* * p<0.05)$. Cells on BCP1 in OS medium had higher osteopontin expression as compared to MSCs on tissue culture polystyrene in OS medium at all time points $(* * p<0.05) . O S$ osteogenic medium. Values are mean $\pm \mathrm{SE}$
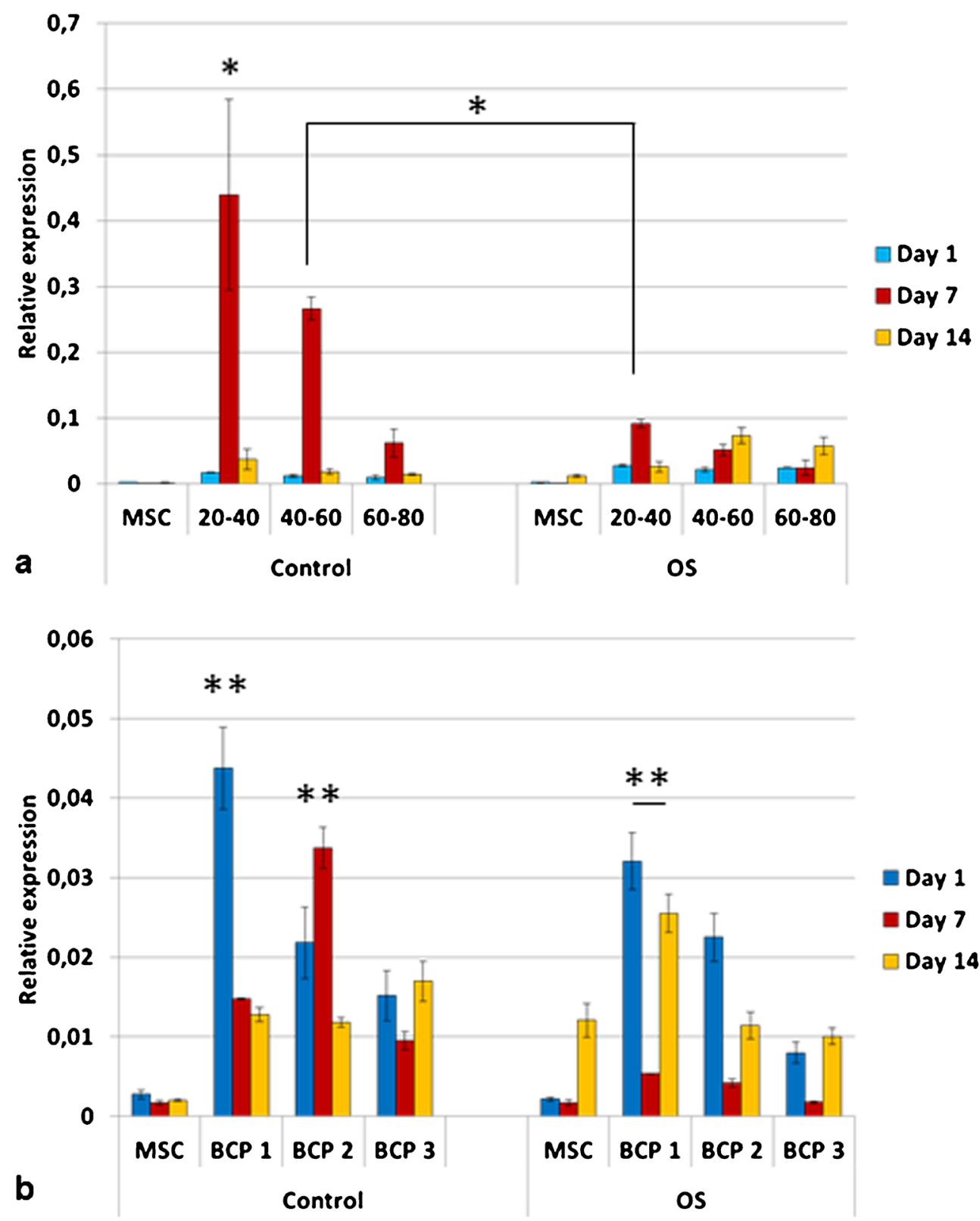

\section{Discussion}

This study compares the effect of six different biphasic calcium phosphate scaffolds, divided into two major groups, granules and blocks, on adhesion, viability, proliferation and osteogenic differentiation of MSCs. It also compares the expression of early markers of osteogenic differentiation of stem cells isolated from distinct sources cultured on a granular form of BCP. Cells are grown in two different culture media, basal (control) and osteoinductive.

Besides differing in physical form (granules of various sizes versus blocks), the BCPs also differed in chemical composition. Variations in both parameters (chemical and physical) have been related to the creation of distinct microenvironments, which can directly modulate cell responses as cells respond to both intrinsic and extrinsic (host microenvironment) factors (Ohgushi and Caplan 1999; Batouli et al. 2003; Rochet et al. 2003; Knothe Tate et al. 2008; Lee et al. 2013).

The biomaterials' physical structures, including the frequency, size and shape of the pores, are a result of the manufacturing process and have been shown to play a role in several stages of new bone formation, such as cell adhesion and tissue ingrowth, after biomaterial implantation (Cheng et al. 2010; Xia et al. 2014). Although porosity was not quantified in this study, these materials contained pore structures at both the micro- and macroscale. Increased porosity leads to increased specific surface area, which also influences the 
Fig. 10 Gene expression profile of mesenchymal stem cells (MSC) seeded on tissue culture plate (TCP) (a) and on biphasic calcium phosphate bioceramics (BCP) (b), in control and OS media. Predominance of RUNX2 and SOX9 co-expression was observed mainly in control media in both surfaces (TCP and BCP), as well as on BCP in OS medium, indicating osteochondrogenic differentiation. PPAR $\gamma$ was upregulated when OS medium was used. $O S$ osteoinductive medium $\left({ }^{*} p<0.05\right)$. Values were normalized to the housekeeping gene GAPDH. Values are mean $\pm \mathrm{SE}$
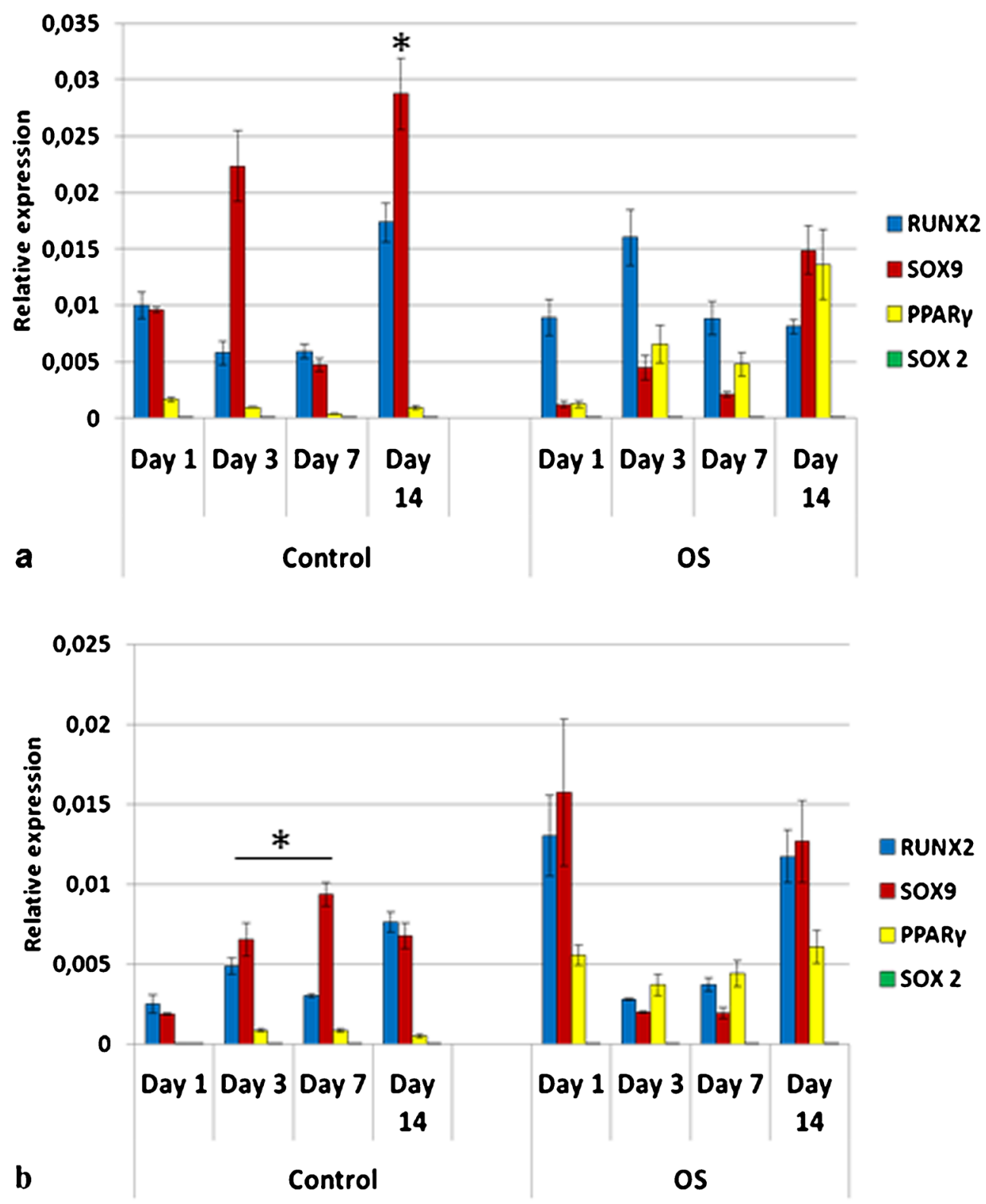

scaffold solubilization (increased surface area favors solubilization/bioresorption) (Cheng et al. 2010). On the other hand, higher porosity generally lowers biomaterials' mechanical properties regardless of their chemical composition (Lin et al. 2007). Specific surface area has also been correlated to cell number: the higher the specific surface area (which is the case of BCP surfaces compared to the flat surfaces of tissue culture plates), the higher the number of attached cells (O'Brien et al. 2005). Scaffolds' solubilization/bioresorption are a function not only of physical structure but also of the scaffold's chemical composition and crystallinity. Amorphous biomaterials, such as tricalcium phosphates, favor solubilization over the crystalline ones, such as hydroxyapatites (LeGeros 1993; Lee et al. 2013).
Whereas macroporosity favors cell colonization and tissue ingrowth, the microporosity has been related mostly to the biomaterial's capacity to adsorb biological fluids (including the entrapment of proteins and other molecules - exogenous or those presented in the site of surgical implantation) (Ripamonti 1996; Cheng et al. 2010; Schumacher et al. 2010; Verron et al. 2010; Yuan et al. 2010). Such protein adsorption, which is also a consequence of the biomaterials' surface charge and wettability, has been considered the major leading factor responsible for the intrinsic osteoinductivity elicited by some but not all BCPs (Ripamonti 1996; Cheng et al. 2010; Yuan et al. 2010). Considering that the BCP scaffolds analyzed here were rich in micropores, this may have been a contributing factor for the upregulation of osteopontin and bone sialoprotein, two late markers of osteogenic 
Fig. 11 Gene expression profile of adipose derived stem cells (ADSC) seeded on tissue culture plate (TCP) (a) and on biphasic calcium phosphate bioceramics (BCP) (b), in both control and OS media. Co-expression of RUNX2 and SOX9 was observed in all experimental conditions. However, significant upregulation of PPAR $\gamma$ was observed when cells were cultured in OS media, mostly on TCP, although its expression was also detected in control media. OS osteoinductive medium $\left({ }^{*} p<0.05\right)$. Values were normalized to the housekeeping gene GAPDH. Values are mean $\pm \mathrm{SE}$
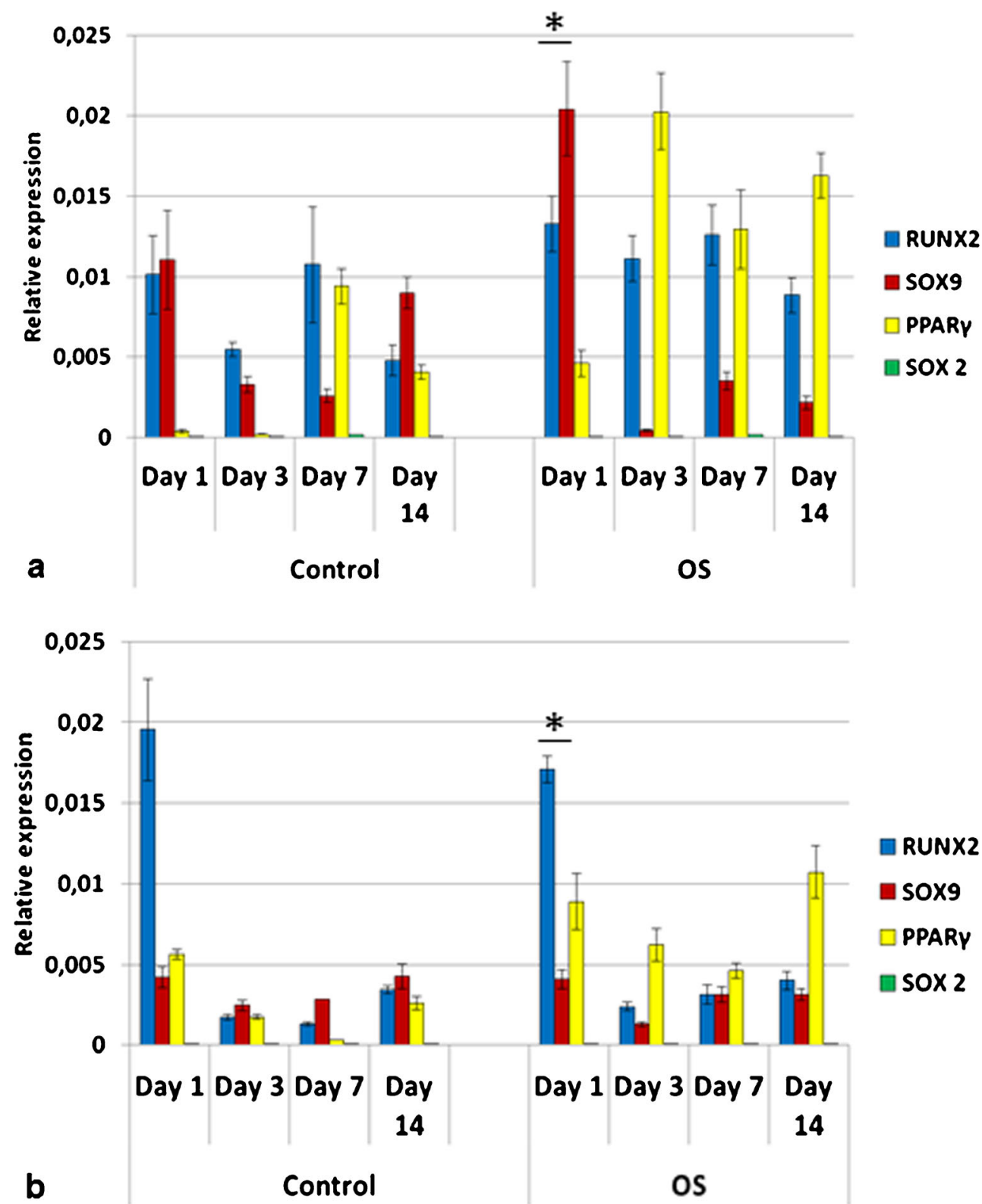

differentiation, observed with cells grown in control media. The nanostructured surface may also have contributed to such response as already reported in the literature ( $\mathrm{Li}$ et al. 2012). These findings suggested that the BCPs may be osteoinductive and not only osteoconductive materials.

Here, the influence of presentation form on cell response was made evident mainly by the comparison of the granules with the BCP1 block. Overall granules favored cell proliferation and differentiation over blocks. In control medium, larger granules promoted cell differentiation, as observed by gene expression analyses, compared to smaller ones. Moreover, the presence of physical features, specifically micro- and macropores of a biomaterial can substantially improve cell viability, proliferation and differentiation as observed with cells on $\mathrm{BCP} 2$ group. The importance of chemical composition has been emphasized by the comparison of BCP1 and BCP3 groups. Calcium phosphate bioceramics have been shown to enrich the microenvironment through calcium and phosphate ion release (Lin et al. 2007; Lee et al. 2013; Shih et al. 2014), otherwise provided by the calcium levels in the media (Huang et al. 2007) and the addition of $\beta$ glycerophosphate (a source of phosphate ions) in the osteogenic induction media (Beck et al. 2000). An optimal balance of calcium and phosphate ions in the microenvironment should exist in order to promote a favorable cell response. However, there is evidence in the literature demonstrating that the concentrations of the released ions from calcium phosphate-based biomaterials-hydroxyapatite, hydroxyapatite-collagen composite and calcium metaphosphate - do not interfere in adhesion and proliferation of 
Fig. 12 Gene expression profile of dental pulp stem cells (DPSC) seeded on tissue culture plate (TCP) (a) and on biphasic calcium phosphate bioceramic (BCP) (b), in both control and OS media. Cells did not express PPAR $\gamma$, except in OS medium on TCP (a). When cultured on BCP in both media, DPSC showed upregulation of SOX9 over RUNX2 at all time points (b). OS osteoinductive medium $\left({ }^{*} p<0.05\right)$. Values were normalized to the housekeeping gene GAPDH. Values are mean $\pm \mathrm{SE}$
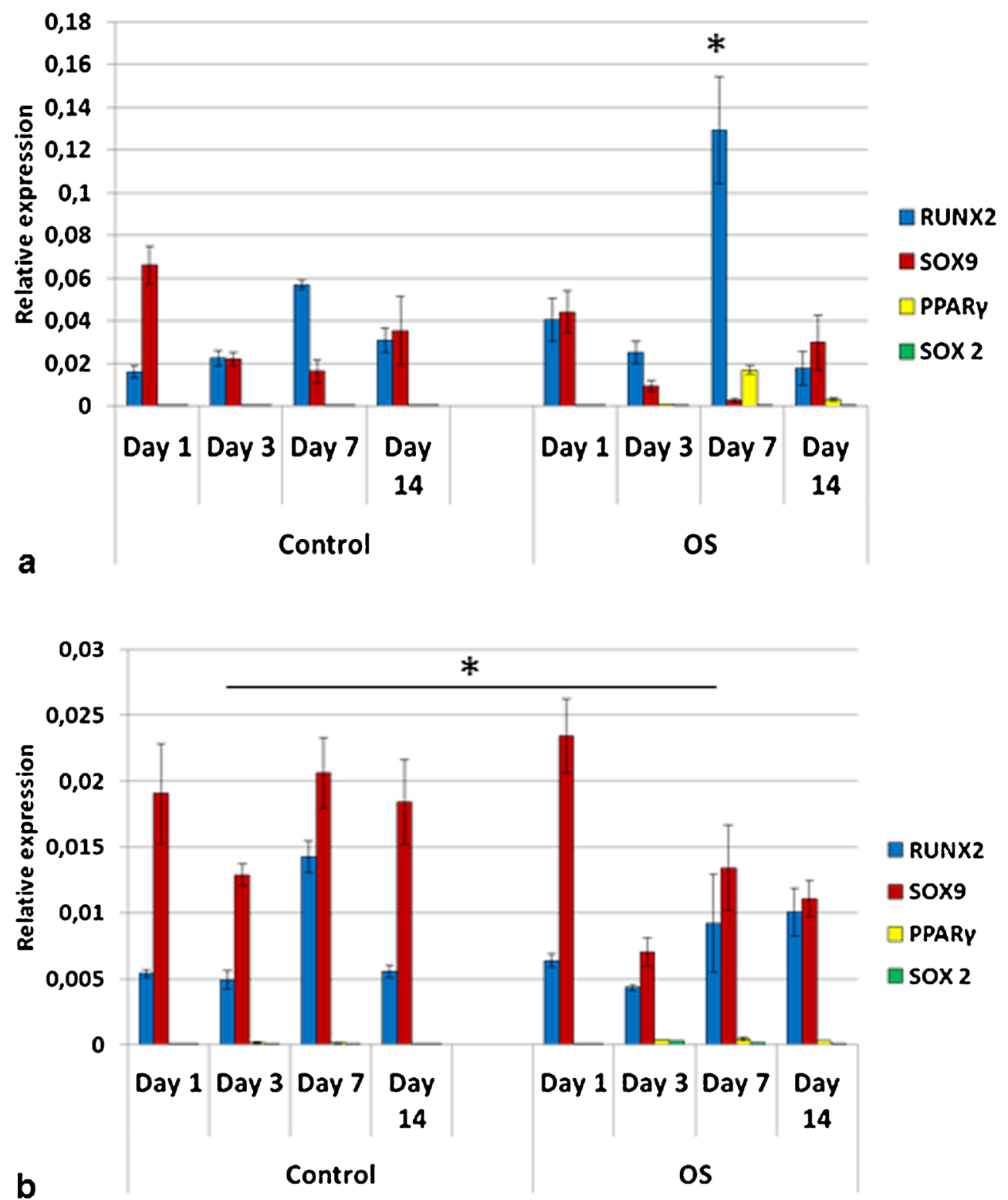

adipose-derived stem cells and osteoblast-like cells (MC3T3) (Lee et al. 2013). In spite of that, hydroxyapatites have elicited greater expression of alkaline phosphatase m-RNA than hydroxyapatite-collagen composite and calcium metaphosphate (Lee et al. 2013).

Cell proliferation and differentiation are highly coordinated and inversely correlated processes: the more undifferentiated the cells, the higher their proliferative potential (Zhu and Skoultchi 2001). An increase in the number of cells cultured in osteogenic media at day 11 may indicate an efficient MSC proliferation prior to osteogenic differentiation, which occurred at day 14. Such an event has been previously reported and related to the proliferative stage that is part of the osteogenic differentiation (Huang et al. 2007). In our study, cells cultured in OS media were lower in number compared to those in control media.
In the present study, the alkaline phosphatase activity remained low in the groups where cells were cultured in control media, with and without biomaterials. These data suggest that the bioceramics may have induced the osteogenic differentiation of MSCs (observed by the gene expression analyses) but cells may not have progressed within the osteoblastic lineage maturation. Although the ALP measurement has been commonly used to demonstrate osteogenic differentiation, this assay should not be considered conclusive (Weir and $\mathrm{Xu}$ 2010).

However, for a biomaterial to be osteoinductive, it must trigger (at early stages of differentiation) genes responsible for directing stem cell fate. Osteoinduction, i.e., the commitment of undifferentiated and/or immature cells toward the osteoprogenitor cell lineage, represents the starting point of the highly coordinated process of osteogenesis (Albrektsson 
Fig. 13 Gene expression profile of pre-osteoblasts (MG-63) seeded on tissue culture plate (TCP) (a) and on biphasic calcium phosphate bioceramics (BCP) (b), in both control and OS media. Significant expression of SOX9 was observed in all experimental conditions. MG-63 expressed bone sialoprotein only on BCP (b) but not on TCP (a). On BCP, BSP levels were higher in control as opposed to OS media (b). RUNX2 was detected at later time points (days 7 and 14) and was upregulated on $\mathrm{BCP}$ as compared to TCP. RUNX2 expression was higher on $\mathrm{BCP}$ OS than on BCP control, on day 14. $O S$ osteoinductive medium $\left({ }^{*} p<0.05\right)$. Values were normalized to the housekeeping gene GAPDH. Values are mean $\pm \mathrm{SE}$
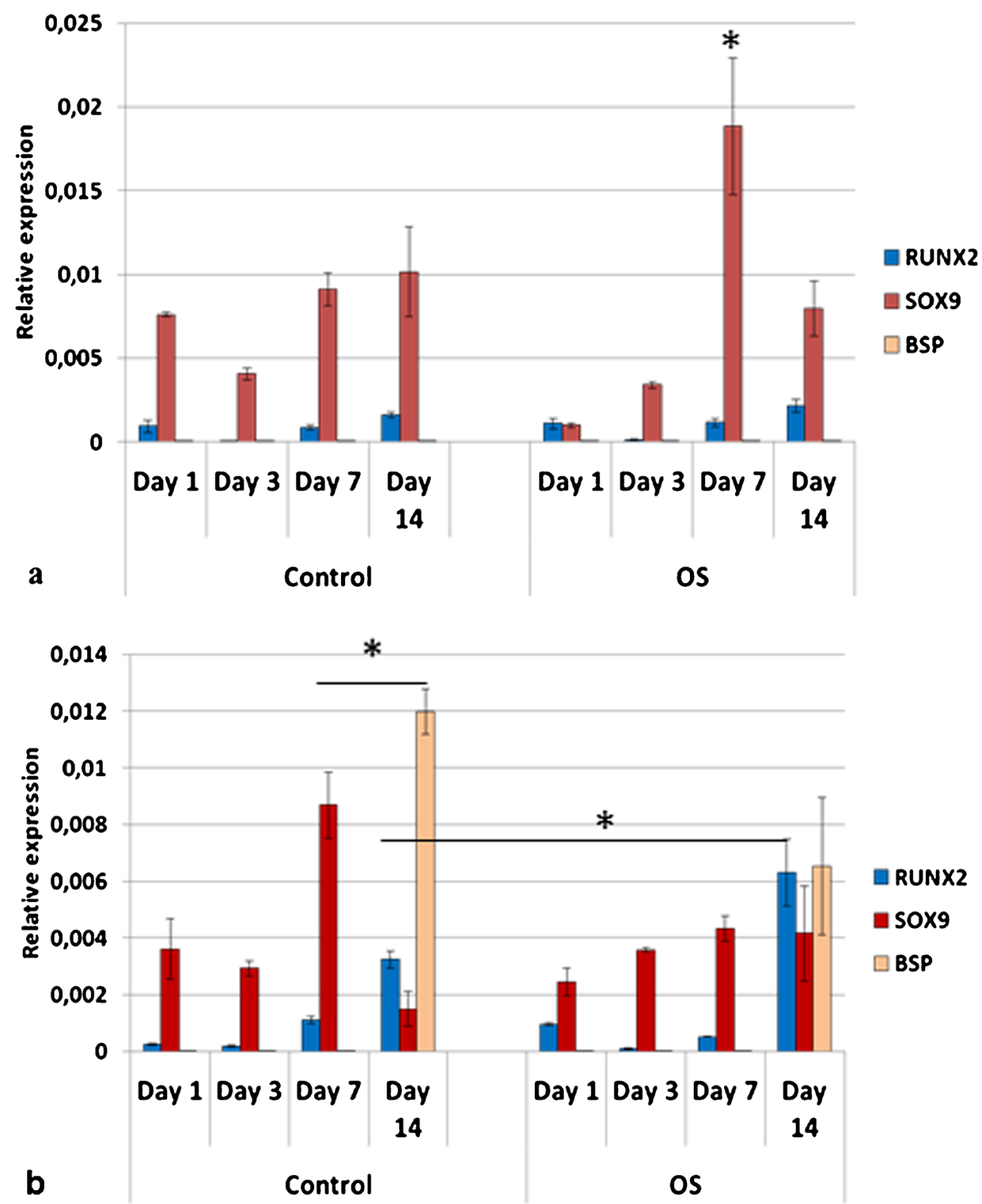

and Johansson 2001; Baglio et al. 2013). In order to test the osteoinductive capacity of the BCP, we investigated the expression of genes responsible for the determination of stem cell fate, at early stages of differentiation (RUNX2, SOX9, $\operatorname{PPAR} \gamma$ ), of multiple cell types. Therefore, stem cells isolated from different sources (bone marrow, adipose tissue and dental pulp) and pre-osteoblasts (MG-63) were cultured on the BCP that showed the highest expression of BSP and OPN, i.e., G20-40.

The levels and patterns of gene expression observed with the stem cells cultured directly on TCP and in C media demonstrated that they are inherently distinct. Variations in the yield of cells, colony frequency, multipotency, proliferation rate, immunomodulatory properties, cytokine secretion, morphology, immunophenotype, transcriptome and proteome are some of the differences that have been previously reported (Shi et al. 2001; Kern et al. 2006; Bochev et al. 2008; Peng et al. 2008; Rebelatto et al. 2008; Huang et al. 2009; Strioga et al. 2012; Hu et al. 2013; Jin et al. 2013; Melief et al. 2013).

Mesenchymal fate and osteochondrogenesis, for endochondral bone formation, are regulated by intricate pathways where RUNX2 and SOX9 are the key transcription factors (Zou et al. 2006; Grässel et al. 2009; Cheng and Genever 2010). Both are co-expressed by osteochondroprogenitor precursor cells that are found in the adult periosteum and endosteum and in fetal perichondrium, as well as in mandibular secondary cartilages such as in the mandibular condyle and Meckel's cartilage (Leucht et al. 2008; Zhang et al. 2013).

RUNX2 (aka Osf2/Cbfa1, Pepb2 $\alpha 1$ or AML3) is a critical regulator of skeletal development, being observed in the 

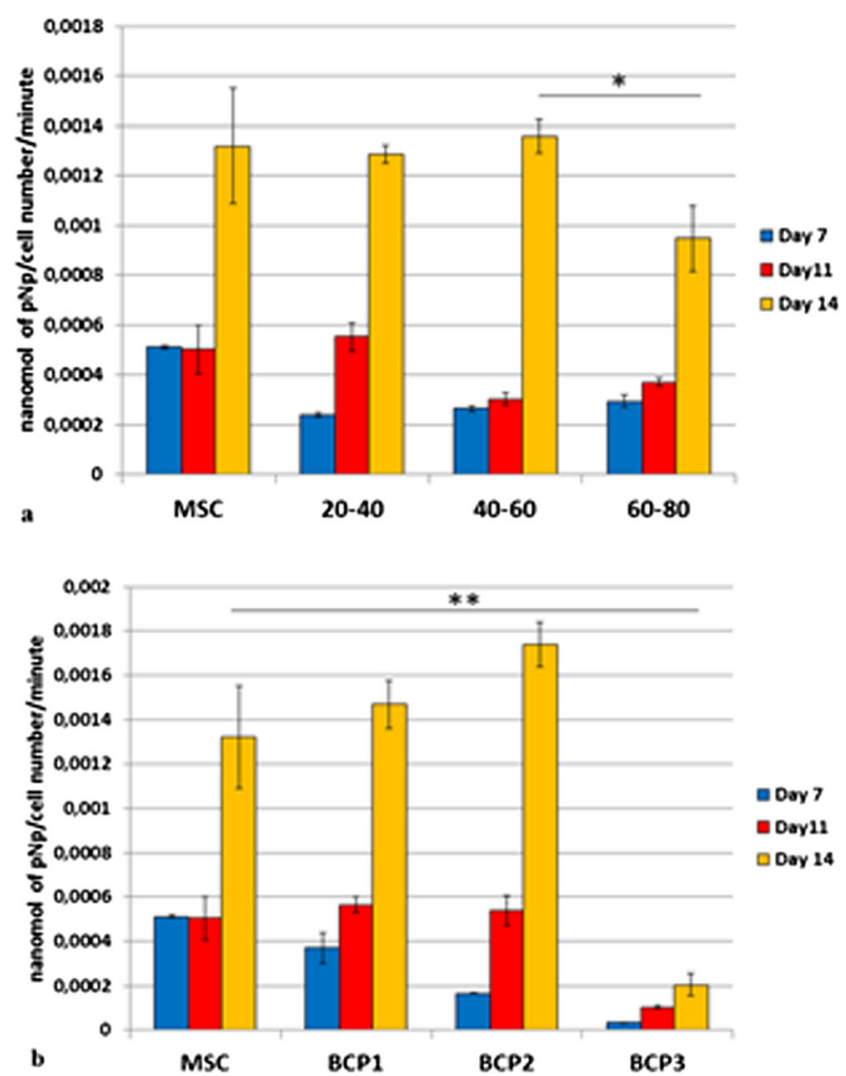

Fig. 14 Alkaline phosphatase (ALP) activity of mesenchymal stem cells on the granules (a) and blocks (b), in osteogenic media. The production of ALP increased over time, from day 1 to 14 , for all the groups $\left({ }^{*} p<0.05\right)$. Cells grown in control medium, with and without biomaterial, did not show ALP activity (data not shown). All groups presented the highest production of ALP at day 14. BCP2 at that time point (day 14) showed the highest ALP activity among all groups $(* * p<0.05)$. MSC, G20-40 and G40-60 were statistically equivalent but were higher than G60-80 at day $14\left({ }^{*} p<0.05\right)$. Values are mean $\pm \mathrm{SE}$

mesenchymal condensations of the developing skeleton, and is the master factor that controls osteoblastic differentiation and chondrocyte maturation (Karsenty 1998; Lian et al. 2006; Zou et al. 2006; Komori 2010; Ding et al. 2012; Nishimura et al. 2012). RUNX2 integrates signaling pathways such as BMP/TGFbeta, Wnt, and Src (Lian et al. 2006), and activates the promoters of several bone protein genes such as COL1a1 (Komori 2010). On the other hand, SOX9 is known to be a marker gene of chondrocytic phenotype besides playing pivotal roles in the organogenesis of several organs (Akiyama et al. 2002; Akiyama 2008; Nishimura et al. 2012; Zhang et al. 2013). The co-expression of RUNX2 and SOX9 resembles the pattern of gene expression normally observed in endochondral bone formation (Leucht et al. 2008; Cheng et al. 2010).

PPAR $\gamma$ is the master regulator of adipogenesis (Lee et al. 2013). Its suppression has been shown to increase the mRNA levels of BMP2, RUNX2, osteocalcin and alkaline phosphatase of ADSC, thus enhancing its osteogenic differentiation
(Lee et al. 2013). The maintenance of PPAR $\gamma$ expression by ADSC observed throughout this study suggests that long-term analysis of in vivo bone formation should be performed to verify the quality of the newly formed bone and its capacity to reestablish the physiological turn-over of the bone tissue. Conversely, ADSCs have been shown to be more promising to reconstitute hematopoiesis of irradiated mice than MSCs (Nakao et al. 2010).

DPSC expressed predominantly RUNX2 and SOX9. However, it is important to note that odontoblast and osteoblast share potent regulators and are similar in terms of immunophenotype and the expression of matrix proteins (Nakashima et al. 1994; Gronthos et al. 2000). Nevertheless, the application of DPSC for bone tissue engineering strategies is questioned due to evidence that these cells generate a dentin-like structure in vivo instead of lamellar bone as observed with MSCs (Gronthos et al. 2000). On the other hand, other authors have reported the formation of mature bone using dental pulp stem cells isolated from deciduous teeth instead of permanent teeth (de Mendonça Costa et al. 2008).

Bone sialoprotein (BSP) encodes a major bone matrix structural phosphoprotein that presents an Arg-Gly-Asp (RGD) cell-attachment sequence (Oldberg et al. 1988) and is known to be involved in the nucleation of hydroxyapatite during bone mineralization (Ogata 2008). The fact that preosteoblasts expressed BSP only when cultured on BCP scaffolds suggests that these biomaterials may foster the progression of pre-osteoblast differentiation toward a more mature cell phase than TCP. SOX2 is an important transcription factor for the maintenance of the self-renewal capacity of embryonic stem cells, among other functions (Avilion et al. 2003; Luo et al. 2013). It was used as a negative control in this study. SOX2 was detected at very low levels for MSCs but not for all other cell types.

The significance of this study relies on the demonstration that bioceramics with either similar chemical composition, but distinct physical features or vice versa, elicit diverse response (proliferation vs. differentiation) of stem cells and that these, when isolated from various tissues, differ in their gene expression profile at early stages of osteogenic differentiation when in contact with the same type of scaffold (equal chemical and physical structure). These data may be taken into account for further tissue engineering strategies.

\section{Conclusion}

This study concluded that stem cells isolated from various origins are inherently different and their behavior can be influenced by BCP scaffolds. Bioceramics, depending on their chemical composition and physical features, may favor either stem cell proliferation (small granules) or differentiation (large granules). Blocks of bioceramics presenting rough surfaces 
and a higher number of micro- and macroporosity favor cell viability, proliferation and differentiation over biomaterials with smooth surfaces and less porosity, even if their chemical composition is considered less favorable for osteogenesis. Long-term in vivo studies will be required to determine the quality of newly formed bone promoted by stem cells from different tissue sources.

Acknowledgments The authors pay tribute to the late Dr Racquel LeGeros, in whose laboratory part of this study was performed; her friendship, guidance and legacy will be remembered forever. This study was supported by EINCO Biomaterial Ltda (Belo Horizonte, Minas Gerais, Brazil) and CAPES (Coordenação de Aperfeiçoamento de Pessoal de Nível Superior), Brazil.

Open Access This article is distributed under the terms of the Creative Commons Attribution License which permits any use, distribution, and reproduction in any medium, provided the original author(s) and the source are credited.

\section{References}

Akiyama H (2008) Control of chondrogenesis by the transcription factor Sox9. Mod Rheumatol 18:213-219

Akiyama H, Chaboissier MC, Martin JF, Schedl A, de Crombrugghe B (2002) The transcription factor Sox 9 has essential roles in successive steps of the chondrocyte differentiation pathway and is required for expression of Sox5 and Sox6. Genes Dev 16:2813-2828

Albrektsson T, Johansson C (2001) Osteoinduction, osteoconduction and osseointegration. Eur Spine J 10(Suppl 2):S96-S101

Arinzeh TL, Tran T, Mcalary J, Daculsi G (2005) A comparative study of biphasic calcium phosphate ceramics for human mesenchymal stem-cell-induced bone formation. Biomaterials 26:3631-3638

Avilion AA, Nicolis SK, Pevny LH, Perez L, Vivian N, Lovell-Badge R (2003) Multipotent cell lineages in early mouse development depend on SOX2 function. Genes Dev 17:126-140

Baglio SR, Devescovi V, Granchi D, Baldini N (2013) MicroRNA expression profiling of human bone marrow mesenchymal stem cells during osteogenic differentiation reveals Osterix regulation by miR31. Gene 527:321-331

Barradas AM, Yuan H, van Blitterswijk CA, Habibovic P (2011) Osteoinductive biomaterials: current knowledge of properties, experimental models and biological mechanisms. Eur Cell Mater 21: 407-429

Batouli S, Miura M, Brahim J, Tsutsui TW, Fisher LW, Gronthos S, Robey PG, Shi S (2003) Comparison of stem-cell-mediated osteogenesis and dentinogenesis. J Dent Res 82:976-981

Beck GR Jr, Zerler B, Moran E (2000) Phosphate is a specific signal for induction of osteopontin gene expression. Proc Natl Acad Sci U S A 97:8352-8357

Bochev I, Elmadjian G, Kyurkchiev D, Tzvetanov L, Altankova I, Tivchev P, Kyurkchiev S (2008) Mesenchymal stem cells from human bone marrow or adipose tissue differently modulate mitogenstimulated B-cell immunoglobulin production in vitro. Cell Biol Int 32:384-393

Briggs T, Treiser MD, Holmes PF, Kohn J, Moghe PV, Arinzeh TL (2009) Osteogenic differentiation of human mesenchymal stem cells on poly(ethylene glycol)-variant biomaterials. J Biomed Mater Res A 91:975-984

Cheng A, Genever PG (2010) SOX9 determines RUNX2 transactivity by directing intracellular degradation. J Bone Miner Res 25:2680-2689
Cheng L, Ye F, Yang R, Lu X, Shi Y, Li L, Fan H, Bu H (2010) Osteoinduction of hydroxyapatite/beta-tricalcium phosphate bioceramics in mice with a fractured fibula. Acta Biomater 6: 1569-1574

de Mendonça Costa A, Bueno DF, Martins MT, Kerkis I, Kerkis A, Fanganiello RD, Cerruti H, Alonso N, Passos-Bueno MR (2008) Reconstruction of large cranial defects in nonimmunosuppressed experimental design with human dental pulp stem cells. J Craniofac Surg 19:204-210

de Oliveira RS, Brigado R, Madureira JF, Cruz AA, de Mello Filho FV, Alonso N, Machado HR (2007) Reconstruction of a large complex skull defect in a child: a case report and literature review. Childs Nerv Syst 23:1097-1102

Ding M, Lu Y, Abbassi S, Li F, Song Y, Geoffroy V, Im HJ, Zheng Q (2012) Targeting Runx2 expression in hypertrophic chondrocytes impairs endochondral ossification during early skeletal development. J Cell Physiol 227:3446-3456

Fellah BH, Delorme B, Sohier J, Magner D, Hardouin P, Layrolle P (2010) Macrophage and osteoblast responses to biphasic calcium phosphate microparticles. J Biomed Mater Res A 93:1588-1595

Garrido CA, Lobo SE, Turibio FM, LeGeros RZ (2011) Biphasic calcium phosphate bioceramics for orthopaedic reconstructions: clinical outcomes. Int J Biomater 2011:129727

Grässel S, Ahmed N, Göttl C, Grifka J (2009) Gene and protein expression profile of naive and osteo-chondrogenically differentiated rat bone marrow-derived mesenchymal progenitor cells. Int J Mol Med 23:745-755

Gronthos S (2011) The therapeutic potential of dental pulp cells: more than pulp fiction? Cytotherapy 13:1162-1163

Gronthos S, Mankani M, Brahim J, Robey PG, Shi S (2000) Postnatal human dental pulp stem cells (DPSCs) in vitro and in vivo. Proc Natl Acad Sci U S A 97:13625-13630

Harasymiak-Krzyzanowska I, Niedojadlo A, Karwat J, Kotula L, GilKulik P, Sawiuk M, Kocki J (2013) Adipose tissue-derived stem cells show considerable promise for regenerative medicine applications. Cell Mol Biol Lett 18:479-493

Hu L, Hu J, Zhao J, Liu J, Ouyang W, Yang C, Gong N, Du L, Khanal A, Chen L (2013) Side-by-side comparison of the biological characteristics of human umbilical cord and adipose tissue-derived mesenchymal stem cells. Biomed Res Int 2013:438243

Huang Z, Nelson ER, Smith RL, Goodman SB (2007) The sequential expression profiles of growth factors from osteoprogenitors [correction of osteroprogenitors] to osteoblasts in vitro. Tissue Eng 13: 2311-2320

Huang GT, Gronthos S, Shi S (2009) Mesenchymal stem cells derived from dental tissue vs. those from other sources: their biology and role in regenerative medicine. J Dent Res 88:792-806

Jin HJ, Bae YK, Kim M, Kwon SJ, Jeon HB, Choi SJ, Kim SW, Yang YS, Oh W, Chang JW (2013) Comparative analysis of human mesenchymal stem cells from bone marrow, adipose tissue, and umbilical cord blood as sources of cell therapy. Int J Mol Sci 14:17986-18001

Karsenty G (1998) Transcriptional regulation of osteoblast differentiation during development. Front Biosci 3:d834-d837

Kerkis I, Caplan AI (2012) Stem cells in dental pulp of deciduous teeth. Tissue Eng B 18:129-138

Kerkis I, Kerkis A, Dozortsev D, Stukart-Parsons GC, Gomes Massironi SM, Pereira LV, Caplan AI, Cerruti HF (2006) Isolation and characterization of a population of immature dental pulp stem cells expressing OCT-4 and other embryonic stem cell markers. Cells Tissues Organs 184:105-116

Kern S, Eichler H, Stoeve J, Klüter H, Bieback K (2006) Comparative analysis of mesenchymal stem cells from bone marrow, umbilical cord blood, or adipose tissue. Stem Cells 24:1294-1301

Knothe Tate ML, Falls TD, McBride SH, Atit R, Knothe UR (2008) Mechanical modulation of osteochondroprogenitor cell fate. Int $\mathrm{J}$ Biochem Cell Biol 40:2720-2738 
Komori T (2010) Regulation of bone development and extracellular matrix protein genes by RUNX2. Cell Tissue Res 339:189-195

Laranjeira MS, Fernandes MH, Monteiro FJ (2013) Response of monocultured and co-cultured human microvascular endothelial cells and mesenchymal stem cells to macroporous granules of nanostructured-hydroxyapatite agglomerates. J Biomed Nanotechnol 9:1594-1606

Le Nihouannen D, Duval L, Lecomte A, Julien M, Guicheux J, Daculsi G, Layrolle P (2007) Interactions of total bone marrow cells with increasing quantities of macroporous calcium phosphate ceramic granules. J Mater Sci Mater Med 18:1983-1990

Lee MJ, Chen HT, Ho ML, Chen CH, Chuang SC, Huang SC, Fu YC, Wang GJ, Kang L, Chang JK (2013a) PPAR $\gamma$ silencing enhances osteogenic differentiation of human adipose-derived mesenchymal stem cells. J Cell Mol Med 17:1188-1193

Lee HR, Kim HJ, Ko JS, Choi YS, Ahn MW, Kim S, Do SH (2013b) Comparative characteristics of porous bioceramics for an osteogenic response in vitro and in vivo. PLoS ONE 8:e84272

LeGeros RZ (1993) Biodegradation and bioresorption of calcium phosphate ceramics. Clin Mater 14:65-88

LeGeros RZ (2008) Calcium phosphate-based osteoinductive materials. Chem Rev 108:4742-4753

LeGeros RZ, Lin S, Rohanizadeh R, Mijares D, LeGeros JP (2003) Biphasic calcium phosphate bioceramics: preparation, properties and applications. J Mater Sci Mater Med 14:201-209

Leucht P, Minear S, Ten Berger D, Nusse R, Helms JA (2008) Translating insights from development into regenerative medicine: the function of Wnts in bone biology. Semin Cell Dev Biol 19:434-443

Li B, Liao X, Zheng L, Zhu X, Wang Z, Fan H, Zhang X (2012) Effect of nanostructure on osteoinduction of porous biphasic calcium phosphate ceramics. Acta Biomater 8:3794-3804

Lian JB, Stein GS, Javed A, van Wijnen AJ, Stein JL, Montecino M, Hassan MQ, Gaur T, Lengner CJ, Young DW (2006) Networks and hubs for the transcriptional control of osteoblastogenesis. Rev Endocr Metab Disord 7:1-16

Lin Y, Wang T, Wu L, Jing W, Chen X, Li Z, Liu L, Tang W, Zheng X, Tian W (2007) Ectopic and in situ bone formation of adipose tissuederived stromal cells in biphasic calcium phosphate nanocomposite. J Biomed Mater Res A 81:900-910

Livingston TL, Gordon S, Archambault M, Kadiyala S, Mcintosh K, Smith A, Peter SJ (2003) Mesenchymal stem cells combined with biphasic calcium phosphate ceramics promote bone regeneration. J Mater Sci Mater Med 14:211-218

Lobo SE, Livingston Arinzeh T (2010) Biphasic calcium phosphate ceramics for bone regeneration and tissue engineering applications. Materials 3:815-826

Luo W, Li S, Peng B, Ye Y, Deng X, Yao K (2013) Embryonic stem cells markers SOX2, OCT4 and Nanog expression and their correlations with epithelial-mesenchymal transition in nasopharyngeal carcinoma. PLoS ONE 8:e56324

Marcacci M, Kon E, Moukhachev V, Lavroukov A, Kutepov S, Quarto R, Mastrogiacomo M, Cancedda R (2007) Stem cells associated with macroporous bioceramics for long bone repair: 6- to 7- year outcome of a pilot clinical study. Tissue Eng 13:947-955

Mastrogiacomo M, Scaglione S, Martinetti R, Dolcini L, Beltrame F, Cancedda R, Quarto R (2006) Role of scaffold internal structure on in vivo bone formation in macroporous calcium phosphate bioceramics. Biomaterials 27:3230-3237

Matsushima A, Kotobuki N, Tadokoro M, Kawate K, Yajima H, Takakura Y, Ohgushi H (2009) In vivo osteogenic capability of human mesenchymal cells cultured on hydroxyapatite and on betatricalcium phosphate. Artif Organs 33:474-481

Melief SM, Zwaginga JJ, Fibbe WE, Roelofs H (2013) Adipose tissuederived multipotent stromal cells have a higher immunomodulatory capacity than their bone marrow-derived counterparts. Stem Cells Transl Med 2:455-463
Nakao N, Nakayama T, Yahata T, Muguruma Y, Saito S, Miyata Y, Yamamoto K, Naoe T (2010) Adipose tissue-derived mesenchymal stem cells facilitate hematopoiesis in vitro and in vivo: advantages over bone marrow-derived mesenchymal stem cells. Am J Pathol 177:547-554

Nakashima M, Nagasawa H, Yamada Y, Reddi AH (1994) Regulatory role of transforming growth factor-beta, bone morphogenetic protein-2, and protein- 4 on gene expression of extracellular matrix proteins and differentiation of dental pulp cells. Dev Biol 162:18-28

Nishimura R, Hata K, Matsubara T, Wakabayashi M, Yoneda T (2012) Regulation of bone and cartilage development by network between BMP signaling and transcription factors. J Biochem 151:247-254

O'Brien FJ, Harley BA, Yannas IV, Gibson LJ (2005) The effect of pore size on cell adhesion in collagen - GAG scaffolds. Biomaterials 26: 433-441

Ogata Y (2008) Bone sialoprotein and its transcriptional regulatory mechanism. J Periodontal Res 43:127-135

Ohgushi H, Caplan AI (1999) Stem cell technology and bioceramics: from cell to gene engineering. J Biomed Mater Res 48:913-927

Oldberg A, Franzén A, Heinegård D (1988) The primary structure of a cell-binding bone sialoprotein. J Biol Chem 263:19430-19432

Peng L, Jia Z, Yin X, Zhang X, Liu Y, Chen P, Ma K, Zhou C (2008) Comparative analysis of mesenchymal stem cells from bone marrow, cartilage and adipose tissue. Stem Cells Dev 17:761-773

Rebelatto CK, Aguiar AM, Moretão MP, Senegaglia AC, Hansen P, Barchiki F, Oliveira J, Martins J, Kuligovski C, Mansur F, Christofis A, Amaral VF, Brofman PS, Goldenberg S, Nakao LS, Correa A (2008) Dissimilar differentiation of mesenchymal stem cells from bone marrow, umbilical cord blood, and adipose tissue. Exp Biol Med (Maywood) 233:901-913

Ripamonti U (1996) Osteoinduction in porous hydroxyapatite implanted in heterotopic sites of different animal models. Biomaterials $17: 31-35$

Rochet N, Loubat A, Laugier JP, Hofman P, Bouler JM, Daculsi G, Carle GF, Rossi B (2003) Modification of gene expression induced in human osteogenic and osteosarcoma cells by culture on a biphasic calcium phosphate bone substitute. Bone 32:602-610

Rosenbaum AJ, Grande DA, Dines JS (2008) The use of mesenchymal stem cells in tissue engineering: a global assessment. Organogenesis 4:23-27

Saldaña L, Sánchez-Salcedo S, Izquierdo-Barba I, Bensiamar F, Munuera L, Vallet-Regi M, Vilaboa N (2009) Calcium phosphate-based particles influence osteogenic maturation of human mesenchymal stem cells. Acta Biomater 5:1294-1305

Schumacher M, Deisinger U, Detsch R, Ziegler G (2010) Indirect rapid prototyping of biphasic calcium phosphate scaffolds as bone substitutes: influence of phase composition, macroporosity and pore geometry on mechanical properties. J Mater Sci Mater Med 21:3119-3127

Shi S, Robey PG, Gronthos S (2001) Comparison of human dental pulp and bone morrow stromal stem cells by cDNA microarray analysis. Bone 29:532-539

Shih YR, Hwang Y, Phadke A, Kang H, Hwang NS, Caro EJ, Nguyen S, Siu M, Theodorakis EA, Gianneschi NC, Vecchio KS, Chien S, Lee OK, Varghese S (2014) Proc Natl Acad Sci U S A 111:990-995

Strioga M, Viswanathan S, Darinskas A, Slaby O, Michalek J (2012) Same or not the same? comparison of adipose tissue-derived versus bone marrow-derived mesenchymal stem and stromal cells. Stem Cells Dev 21:2724-2752

Teixeira S, Fernandes H, Leusink A, van Blitterswijk C, Ferraz MP, Monteiro FJ, de Boer J (2010) In vivo evaluation of highly macroporous ceramic scaffolds for bone tissue engineering. $J$ Biomed Mater Res A 93:567-575

Temple JP, Hutton DL, Hung BP, Huri PY, Cook CA, Kondragunta R, Jia $X$, Grayson WL (2014) Engineering anatomically shaped 
vascularized bone grafts with hASC and 3D-printed PCL scaffolds. J Biomed Mater Res A. doi:10.1002/jbm.a.35107

Utsunomiya T, Shimada M, Imura S, Morine Y, Ikemoto T, Mori H, Hanaoka J, Iwahashi S, Saito Y, Iwaguro H (2011) Human adipose-derived stem cells: potential clinical applications in surgery. Surg Today 41:18-23

Verron E, Khairoun I, Guicheux J, Bouler JM (2010) Calcium phosphate biomaterials as bone drug delivery systems: a review. Drug Discov Today 15:547-552

Wang L, Fan H, Zhang ZY, Lou AJ, Pei GX, Jiang S, Mu TW, Qin JJ, Chen SY, Jin D (2010) Osteogenesis and angiogenesis of tissue-engineered bone constructed by prevascularized $\beta$ tricalcium phosphate scaffold and mesenchymal stem cells. Biomaterials 31:9452-9461

Weir MD, Xu HH (2010) Osteoblastic induction on calcium phosphate cement-chitosan constructs for bone tissue engineering. J Biomed Mater Res A 94:223-233
Xia L, Lin K, Jiang X, Fang B, Xu Y, Liu J, Zeng D, Zhang M, Zhang X, Chang J, Zhang Z (2014) Effect of nano-structured bioceramic surface on osteogenic differentiation of adipose derived stem cells. Biomaterials 35:8514-8527

Yuan H, Fernandes H, Habibovic P, de Boer J, Barradas AM, de Ruiter A, Walsh WR, van Blitterswijk CA, de Bruijn JD (2010) Osteoinductive ceramics as a synthetic alternative to autologous bone grafting. Proc Natl Acad Sci U S A 107:13614-13619

Zhang H, Zhao X, Zhang Z, Chen W, Zhang X (2013) An immunohistochemical study of Sox9, Runx2, and Osterix expression in the mandibular cartilages of newborn mouse. Biomed Res Int 2013: 265380

Zhu L, Skoultchi AI (2001) Coordinating cell proliferation and differentiation. Curr Opin Genet Dev 11:91-97

Zou L, Zou X, Li H, Mygind T, Zeng Y, Lü N, Bünger C (2006) Molecular mechanism of osteochondroprogenitor fate determination during bone formation. Adv Exp Med Biol 585:431-441 